MALISA MULHOLLAND

\title{
REGULATION OF PROFESSIONAL CLINICAL TRIAL VOLUNTEERS IN NEW ZEALAND
}

\author{
LLM RESEARCH PAPER \\ LAWS 524: HUMAN RIGHTS
}

FACULTY OF LAW

TE WHARE WĀNANGA O TE ŪPOKO O TE IKA A MĀUI

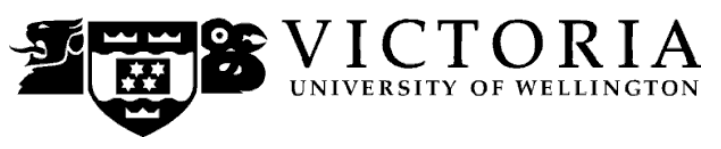

2013 


\section{Contents}

LLM RESEARCH PAPER LAWS 524: HUMAN RIGHTS ............................................1

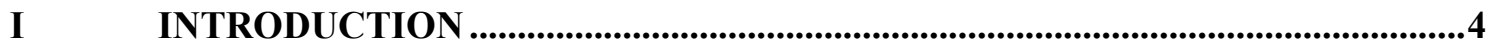

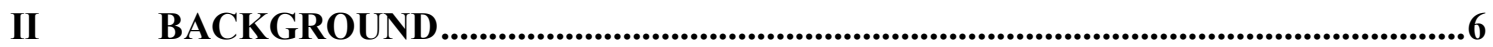

A Clinical Trial Definition .................................................................................................6

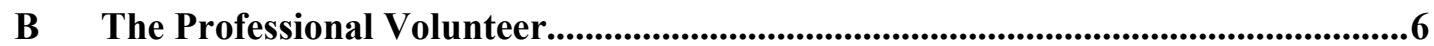

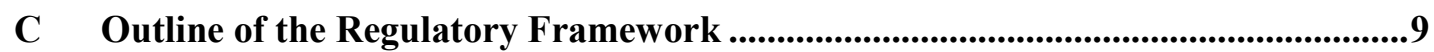

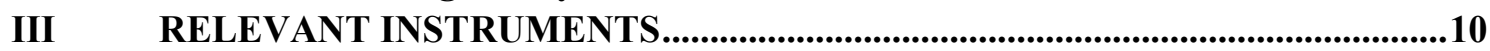

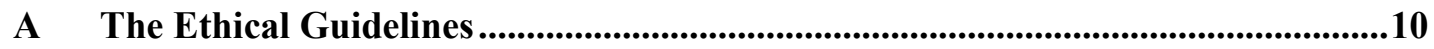

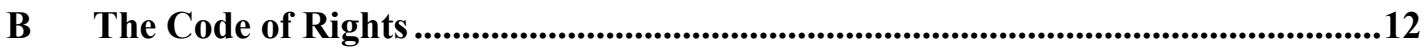

C The New Zealand Bill of Rights Act 1990..........................................................14

1 Section 10 and the definition of consent .................................................14

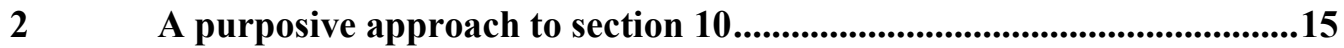

3 The application of the New Zealand Bill of Rights Act 1990 to the Ethical

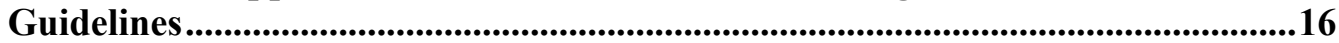

IV ETHICAL DECISION-MAKING AND THE DOMINANCE OF AUTONOMY18

A Ethical Regulation of Clinical Research ............................................................................18

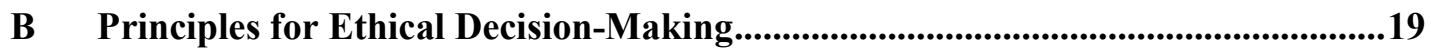

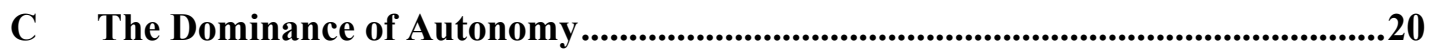

D Balancing Autonomy and Other Interests......................................................................21

$\mathrm{V}$ THE PROBLEM OF THE PROFESSIONAL VOLUNTEER ..............................22

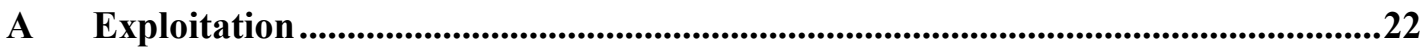

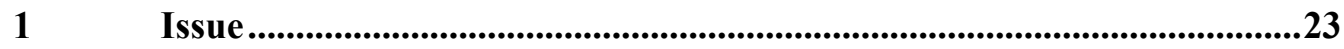

$2 \quad$ Proposals for reform .......................................................................................26

B Unregulated Compounded Risks ..................................................................................30

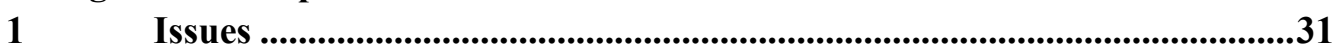

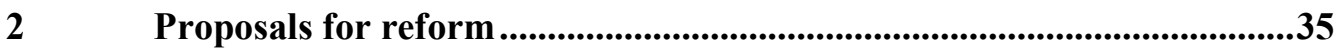

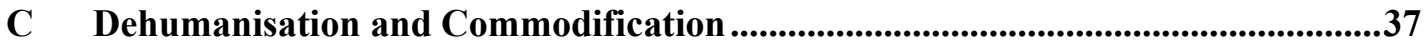

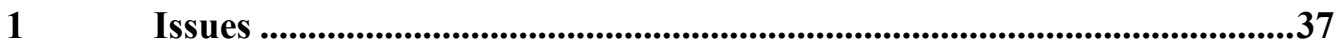

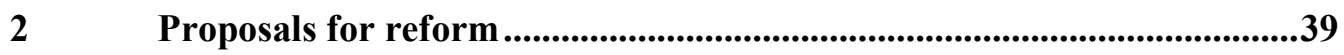

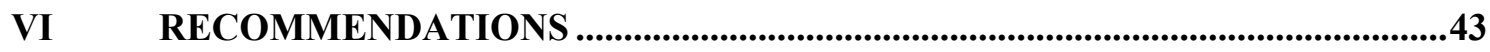

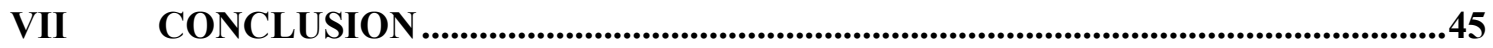




\begin{abstract}
This paper aims to form a starting point for a discussion of the regulation of paid clinical research volunteers (professional volunteers) in New Zealand. It will argue that professional volunteers, who are currently unregulated as a class of research participants, present unique issues which are not addressed by existing regulation. The major arguments will be that: by restricting the value of financial compensation that can be provided for volunteering in a clinical trial, existing regulation allows professional volunteers to be exploited; professional volunteers are exposed to unregulated compounded risks and it is unlikely that they are properly informed of these risks; and in failing to recognise the existence of professional volunteers, current regulation fails to address their commodification and dehumanisation. Proposals to address these issues will be evaluated through a human rights lens for consistency with the New Zealand Bill of Rights Act 1990 and the Code of Health and Disability Services Consumers' Rights 1996. Recommendations for reform will be put forward on the basis of this analysis.
\end{abstract}

\title{
Word length
}

The text of this paper (excluding abstract, table of contents, footnotes and bibliography) comprises approximately 14,280 words.

\section{Subjects and Topics}

Human rights - medical experimentation

Clinical research - research ethics

Medical law - health consumer rights 


\section{Introduction}

Human medical experimentation is necessary for medical progress. ${ }^{1}$ Throughout the world, participants enrol in clinical trials so that new drugs can be tested for safety and efficacy. Payment for research participation, while a longstanding practice, is becoming increasingly common. $^{2}$ The focus of this paper is on research participants who repeatedly volunteer in clinical trials for the financial compensation provided for participation (professional volunteers). These individuals are known in the industry as "professional guinea pigs". 3

In his text "The Professional Guinea Pig", Roberto Abadie (Abadie) presents the results of his ethnographic research into self-identified professional guinea pigs in Philadelphia from 20032004. ${ }^{4}$ From his research Abadie makes the following conclusion: ${ }^{5}$

...being paid to test drug safety has become an essential part of the clinical drug trial enterprise in America. Pharmaceutical companies depend upon paid subjects to test an ever increasing number of drugs coming out of their "pipeline", and subjects see their participation not as an altruistic gesture but as their job, a particular kind of trade with some resemblance to a mild torture economy in which bodily pain, boredom, and compliance are exchanged for money...

Abadie's thesis is that unique issues arise in the case of professional guinea pigs which need to be addressed by United States regulation. In particular, he is concerned by the exploitation and dehumanisation of volunteers, the exposure of volunteers to the "cumulative result of drug interactions resulting from years of trial participation", and the pharmaceutical industry's denial of their commodification. ${ }^{6}$ The purpose of this paper is to evaluate whether New Zealand's regulatory framework adequately addresses these issues and to provide recommendations for change where necessary.

\footnotetext{
${ }^{1}$ World Medical Association Declaration of Helsinki - Ethical Principles for Medical Research Involving Human Subjects (adopted by the 18th WMA General Assembly, Helsinki, Finland, June 1964) at A(5).

${ }^{2}$ Neal Dickert and Christine Grady "Incentives for Research Participants" in Ezekiel J Emanuel and others The Oxford Textbook of Clinical Research Ethics (Oxford University Press, New York, 2008) at 386.

${ }^{3}$ At 386.

${ }^{4}$ Roberto Abadie The Professional Guinea Pig: Big Pharma and the Risky World of Human Subjects (Duke University Press, Durham, 2010) at 3.

${ }^{5}$ At 2.

${ }^{6}$ At 157-158.
} 
The general argument will be that current regulation does not adequately address the issues presented by professional volunteers. This paper will present different options for addressing this problem and will evaluate these options through a human rights lens by assessing them for consistency with the New Zealand Bill of Rights Act 1990 and the Code of Health and Disability Services Consumers' Rights 1996 (Code of Rights). In light of this analysis, this paper will provide recommendations on how the regulatory framework could be amended to better address the rights of professional volunteers and to ensure that research is ethical.

Given the specialised nature of this topic, some background information may be required to enable the reader to engage with the issues presented in this paper. Part II therefore begins by explaining what a clinical trial involves, providing information on professional volunteers in New Zealand and giving an outline of the regulatory framework applying to clinical research. Part III will provide further detail on the specific instruments which protect research participants' rights and regulate research ethics. Part IV will introduce the reader to the basic principles of ethical decision-making and will highlight the dominance of autonomy in this area. The balancing of autonomy against other interests will form an underlying theme of this paper. Part V will establish that the existing regulatory framework does not adequately address the issues presented by professional volunteers. It will argue that: by restricting the value of financial compensation that can be provided for volunteering in a clinical trial, existing regulation allows professional volunteers to be exploited; professional volunteers are exposed to unregulated compounded risks and it is unlikely that they are properly informed of these risks; and in failing to recognise the existence of professional volunteers, current regulation fails to address their commodification and dehumanisation. Part $\mathrm{V}$ will include a discussion of different proposals for addressing these issues, and will evaluate these options for consistency with the New Zealand Bill of Rights Act 1990 and the Code of Rights. The recommendations resulting from this discussion will be presented in Part VI.

Professional volunteers are not currently regulated or even recognised as a class of research participants in New Zealand. This paper recommends that this needs to change, but it does not intend to provide a definitive answer to all the issues presented by professional volunteers. The intention is to demonstrate that professional volunteers present issues which warrant further examination. As such, the recommendations in this paper are advanced on the basis that they can provide a starting point for discussion and further debate. This is only the beginning and there is still much to be ironed out, and no doubt other issues and arguments to consider. 


\section{Background}

\section{A Clinical Trial Definition}

Clinical trials test "health-related interventions", such as medicines, devices or new procedures, on human participants in order to evaluate their effects on health outcomes. ${ }^{7}$ A clinical trial is generally split into four phases. ${ }^{8}$ A Phase I study tests the health-related intervention for the first time in humans. Typically, Phase I studies are non-therapeutic, in the sense that they are conducted on healthy "volunteers" (healthy participants are generally referred to as volunteers) ${ }^{9}$ who will not receive any direct therapeutic benefit from participating in the study. One of the purposes of a Phase I study is to test the toxicity of the intervention in humans. ${ }^{10}$ Phase II and III studies test the intervention on patients who are afflicted with the condition that the intervention aims to treat or prevent. Participants in these studies therefore hold the prospect of a therapeutic benefit. Purposes of Phase II and III studies include establishing efficacy (whether the intervention works) and optimum dosage. ${ }^{11}$ Results of Phase I, II and III studies are necessary to gain regulatory approval for the intervention. Phase IV studies test the intervention post regulatory approval. ${ }^{12}$

This paper is restricted to a discussion of first-in-human Phase I clinical trials of medicines in healthy volunteers, that is, trials that test drugs in humans for the first time. Healthy volunteers present an interesting case study because, as this paper will explain, ${ }^{13}$ these participants expose themselves to significantly higher risks than other types of trial participants, without the prospect of any direct therapeutic benefit.

\section{B The Professional Volunteer}

Volunteers may be motivated by altruism, financial gain and/or indebtedness to the researcher (in the case of volunteers who are students or employees of the researcher) to participate in a study

\footnotetext{
${ }_{7}$ National Ethics Advisory Committee Ethical Guidelines for Intervention Studies: Revised edition (Ministry of Health, July 2012) at 39.

${ }^{8}$ At 39.

${ }^{9}$ Gerhard Nahler Dictionary of Pharmaceutical Medicine (2nd ed, Springer, Vienna, 2009) at 190.

${ }^{10}$ National Ethics Advisory Committee, above n 7, at 40.

11 At $40-41$.

12 At 41.

${ }^{13}$ See Part V(B)1(a).
} 
in which they will receive no therapeutic benefit. ${ }^{14}$ The focus of this paper is on volunteers who repeatedly participate in clinical trials, primarily or solely because of the financial compensation provided for participation (professional volunteers).

Abadie's book presents a convincing argument for regulating professional volunteers in the United States. While Abadie acknowledges that there is no reliable data on the number of paid trial participants in the United States, ${ }^{15}$ the number is likely to be significant. In the United States, thousands of Phase I studies are open for recruitment at any point in time and the government administers an easily accessible centralised database of clinical trials which allows volunteers to shop around for the best trials. ${ }^{16}$ This creates the ideal environment for professional volunteers, who form a self-defined and vocal group of trial volunteers in the United States. ${ }^{17}$

In New Zealand the position is considerably different. New Zealand's population is much smaller, and there are far fewer New Zealand based pharmaceutical companies. On average, only 12.5 Phase I clinical trials are approved each year in New Zealand. ${ }^{18}$ It is impossible to estimate the number of individuals who participate in these trials, let alone the number of professional volunteers. While clinical trials must get approval before they are conducted in New Zealand, there is no centralised registry of trial participants and no way of monitoring how many trials volunteers participate in. The author has been unable to find any information on professional volunteers in New Zealand, although it is likely that they are a small population. The first recommendation of this paper is therefore that empirical research into professional volunteers in New Zealand should be conducted, so that regulators can have a better understanding of the impact of the issues addressed in this paper.

\footnotetext{
${ }^{14}$ CL Tishler and S Bartholomae "The recruitment of normal healthy volunteers: A review of the literature on the use of financial incentives" (2002) $42 \mathrm{~J}$ Clin Pharmacol 365 cited in CL Tishler and S Bartholomae "Repeat participation among normal healthy research volunteers: professional guinea pigs in clinical trials?" (2003) 46(4) Perspect Biol Med 508 at 510 .

${ }^{15}$ Abadie, above $\mathrm{n} 4$, at 12.

${ }^{16}$ U.S. National Institutes of Health "ClinicalTrials.gov" <www.clinicaltrials.gov>.

${ }^{17}$ See generally Jim Hogshire Sell Yourself to Science: A Complete Guide to Selling Your Body Organs, Body Fluids, Bodily Functions and Being a Human Guinea Pig (Loompanics Unlimited, Port Townsend, 1992); and Robert Helms "Guinea Pig Zero: An Anthology of the Journal for Human Research Subjects" Guinea Pig Zero $<$ www.guineapigzero.com $>$.

18 Email from Susan Issacs (Standing Committee on Therapeutic Trials administrator) to Malisa Mulholland regarding the average number of Phase I studies approved by the Standing Committee on Therapeutic Trials per year (23 June 2013) (Obtained under Official Information Act 1982 Request to the Standing Committee on Therapeutic Trials).
} 
It is clear that New Zealand does offer opportunities for paid participation in clinical trials and that there are no limits on the number of trials volunteers can participate in. There are several dedicated clinical research service providers in New Zealand, which offer opportunities to healthy volunteers. For example: Auckland Clinical Studies has conducted 46 Phase I studies and boasts a volunteer database of more than 3,500 names; ${ }^{19}$ and Christchurch Clinical Studies Trust has conducted over 115 studies, the majority of which have been Phase I trials in healthy volunteers. ${ }^{20}$ Auckland Clinical Studies and Christchurch Clinical Studies Trust, like other clinical research service providers, invite potential volunteers to sign up online to their volunteer databases, which allow prospective volunteers to be contacted about future clinical trials. The websites of both organisations make it clear that "reimbursement" will be given to volunteers to compensate them for the "inconvenience" of participation. ${ }^{21}$ It therefore appears to be relatively easy to become a professional volunteer in New Zealand and, by having volunteer databases, clinical research service providers appear to welcome this. A recent Stuff article on "human guinea pigs" interviewed four New Zealand volunteers, two of whom had participated in multiple trials. One of the volunteers, described as a "regular", reported receiving $\$ 10,900$ for his recent participation in three trials. ${ }^{22}$ Further, in a 2008 study on New Zealand university students volunteering for clinical trials, thirteen of the eighteen volunteers interviewed had participated in more than one trial. ${ }^{23}$

Even if New Zealand does not currently have a significant population of professional volunteers, this is likely to change. Not only do clinical trials advance medical science, they can also generate income for the public health system. ${ }^{24}$ It has been estimated that, by 2020, New Zealand could be generating $\$ 250$ million annually from clinical trials (given the appropriate environment). ${ }^{25}$ This is part of the reason why Parliament's Health Select Committee conducted an inquiry into improving New Zealand's environment to support clinical trials. ${ }^{26}$ The 2011 report of the Inquiry recommended various changes to make New Zealand a more attractive

\footnotetext{
19 Auckland Clinical Studies "About ACS" <www.clinicalstudies.co.nz $>$; and Auckland Clinical Studies "Completed \& Ongoing Studies" < www.clinicalstudies.co.nz $>$.

${ }^{20}$ Christchurch Clinical Studies Trust "Studies" $<$ www.ccst.co.nz $>$.

${ }^{21}$ Christchurch Clinical Studies Trust "Reimbursement" <www.ccst.co.nz $>$; and Auckland Clinical Studies "Reimbursement" <www.clinicalstudies.co.nz $>$.

${ }^{22}$ Nikki Macdonald "The human guinea pigs" (12 August 2012) stuff.co.nz < www.stuff.co.nz>.

${ }^{23}$ Tolich M "What if Institutional Research Boards (IRBs) treated healthy volunteers in clinical trials as their clients?"(2010) 3(12) AMJ 767 at 767.

${ }^{24}$ See Lyn Murphy and Dr William Maguire "Quantifying the Benefits and Costs of Conducting Sponsored Clinical Trials: Some Preliminary Results" (paper presented to the Auckland Region Accounting Conference, 2010).

${ }^{25}$ Health Committee Inquiry into improving New Zealand's environment to support innovation through clinical trials (June 2011) at 12.

${ }^{26}$ At 13.
} 
country for pharmaceutical companies to conduct trials in, so that these economic benefits could be realised. ${ }^{27}$ The Government has been largely receptive to the report, and has already taken action on a number of its recommendations. ${ }^{28}$ It is therefore possible that clinical trials will become a growing enterprise in New Zealand in the years to come. With more clinical trials on offer the number of professional volunteers is likely to increase.

\section{Outline of the Regulatory Framework}

The Medicines Act 1981 governs the regulation of therapeutic products in New Zealand. Importantly for our purposes, it prohibits the sale, distribution or advertisement of new medicines without the consent of the Minister of Health. ${ }^{29}$ This general prohibition is subject to an exemption for approved clinical trials. ${ }^{30} \mathrm{~A}$ clinical trial is therefore unlawful unless it can fall within this exemption. ${ }^{31}$ In practice, clinical trial approval requires both scientific and ethical approval. These are two separate approval processes, which are not governed by a single instrument. ${ }^{32}$

The New Zealand Medicines and Medical Devices Safety Authority (Medsafe, a business unit of the Ministry of Health) administers the scientific approval of clinical trials under the Medicines Act $1981 .{ }^{33}$ Section 30 of the Medicines Act 1981 requires clinical trials to be approved by the Director-General of Health, on the recommendation of the Health Research Council of New Zealand. The Health Research Council has delegated its power of recommendation to its Standing Committee on Therapeutic Trials. This Standing Committee conducts a "scientific assessment" of clinical trial applications for the purpose of making a recommendation under $\mathrm{s}$

\footnotetext{
27 At 17.

28 Government Response to Report of the Health Committee on its Inquiry into improving New Zealand 's environment to support innovation through clinical trials, presented to the House of Representatives in accordance with Standing Order 248 (J.1) (6 September 2011).

${ }^{29}$ Medicines Act 1981, s 20.

${ }^{30}$ Section 30.

${ }^{31}$ Nicola Peart, Fiona McCrimmon and John Dawson "Clinical Trials" in John Dawson and Nicola Peart The Law of Research: a guide (University of Otago Press, Dunedin, 2003) at 176.

32 New Zealand Medicines and Medical Devices Safety Authority Guideline on the Regulation of Therapeutic Products in New Zealand: Part 11: Clinical trials - regulatory approval and good clinical practice requirements, Edition 1.3 (Ministry of Health, November 2012) at 4.

${ }^{33}$ At 4.
} 
$30 .^{34}$ It is not tasked with considering issues outside this ambit, such as ethical or human rights issues. $^{35}$

Ethical approval for clinical trials is conducted by health and disability ethics committees (ethics committees). ${ }^{36}$ There are four committees, established under the New Zealand Public Health and Disability Act $2000 .{ }^{37}$ Their function is to ensure that research complies with the ethical standards promulgated by the National Ethics Advisory Committee and to grant ethical approval accordingly. ${ }^{38}$ The New Zealand Ethical Guidelines for Intervention Studies (the Ethical Guidelines) apply to clinical trials. ${ }^{39}$

Once approved, trial volunteers' rights are protected through various laws and guidelines, which regulate research at both an international and domestic level. Most relevant to this paper are the Ethical Guidelines, the Code of Rights and the New Zealand Bill of Rights Act 1990. These instruments, and their applicability to research, will be discussed below in Part III.

\section{Relevant Instruments}

\section{A The Ethical Guidelines}

The most exhaustive statement of researcher obligations and research participant protections in New Zealand is found in the Ethical Guidelines. These Guidelines supplement the law, providing comprehensive ethical standards for research (65 pages) to address the unique ethical issues which arise from medical experimentation on humans. The Guidelines are based on various international ethical standards for research. ${ }^{40}$ One of the key objectives of the Ethical Guidelines is to "safeguard the rights and interests of participants in research and innovative practice". ${ }^{4}$

\footnotetext{
${ }^{34}$ Health Research Council of New Zealand "Committees" < www.hrc.govt.nz>.

${ }^{35}$ Health Research Council of New Zealand Standing Committee on Therapeutic Trials: Terms of Reference (New Zealand Government).

${ }^{36}$ New Zealand Medicines and Medical Devices Safety Authority, above n 32, at 4.

${ }^{37}$ New Zealand Public Health and Disability Act 2000, s 11; and Health and Disability Ethics Committees "About the Committees" (26 October 2012) <ethics.health.govt.nz>.

${ }^{38}$ Health and Disability Ethics Committees Terms of Reference: Northern A Health and Disability Ethics Committee at 1; Health and Disability Ethics Committees Terms of Reference: Northern B Health and Disability Ethics Committee at 1; Health and Disability Ethics Committees Terms of Reference: Central Health and Disability Ethics Committee at 1; and Health and Disability Ethics Committees Terms of Reference: Southern Health and Disability Ethics Committee at 1.

${ }^{39}$ National Ethics Advisory Committee, above n 7, at 5.

${ }^{40}$ At 1 .

${ }^{41}$ At iii.
} 
The Ethical Guidelines are relevant at two stages of the clinical trial process. Firstly, as explained above, ${ }^{42}$ ethics committees must review clinical research for consistency with the Ethical Guidelines before it can be conducted in New Zealand. Secondly, the Guidelines apply to researchers when conducting clinical trials. ${ }^{43}$

The Ethical Guidelines offer no specific guidance on professional volunteers (despite making special provisions for research involving children and young people, research involving people with intellectual disabilities, research involving unconscious participants, research involving consumers with a terminal illness, research involving older persons and research involving students, employees and prison inmates). ${ }^{44}$ The only guidance available on professional volunteers is that which applies to research participants generally. Professional volunteers are therefore currently unregulated as a specific class of research participants.

Applicable provisions of the Ethical Guidelines will be discussed as they become relevant to the arguments presented below. At this stage, however, it is useful to note that the Ethical Guidelines are based on the following "underlying ethical considerations": 45

- Respect for persons, incorporating respect for autonomy and protection of people. $^{46}$

- Justice, requiring that "within a population there is a fair distribution of the benefits and burdens of participation in a study and, for any participant, a balance of burdens and benefits." 47

- Beneficence and non-maleficence, referring to the respective "moral obligation[s] to act in a way that will benefit others... [and] not to inflict harm on others". 48

- Integrity, encompassing the researcher's "commitment to the advancement of knowledge". 49

- Diversity, requiring respect and recognition of diversity among research participants. ${ }^{50}$

\footnotetext{
${ }^{42}$ See Part II(C).

${ }^{43}$ National Ethics Advisory Committee, above n 7, at 3.

${ }^{44}$ At 46-61.

${ }^{45}$ At 8 .

${ }^{46}$ At 8 .

${ }^{47}$ At 8 .

${ }^{48}$ At 9.

${ }^{49}$ At 9 .

${ }^{50}$ At 10.
} 
- Addressing conflict of interest. ${ }^{51}$

These underlying considerations will be useful in critiquing current regulation and evaluating the proposals put forward to address the issues set out below. ${ }^{52}$

While both the Code of Rights and New Zealand Bill of Rights Act 1990 also protect the rights of research participants, ${ }^{53}$ the Ethical Guidelines are "the most effective means of preventing potential harm resulting from medical and scientific research on humans". ${ }^{44}$ The Guidelines form the primary means through which research is regulated in New Zealand. They apply at the approval stage and can therefore act to prevent rights issues occurring by prohibiting unethical research. Further, researchers may be subject to disciplinary actions by their employers for breaching the Guidelines, and medical and scientific journals are likely to refuse to publish research which results from unethical research. ${ }^{55}$ Most of the recommendations of this paper will therefore be targeted at improving the Ethical Guidelines.

\section{$B$ The Code of Rights}

The Health and Disability Commissioner Act 1994 sets up the office of the Health and Disability Commissioner and provides for the establishment of the Code of Rights. The Code came into force as a regulation under the Act in $1996 .{ }^{56}$ It provides the following ten rights of consumers and corresponding duties of providers, which apply to consumers and providers of health and disability services: $:^{57}$

- Right 1 - Right to be Treated with Respect.

- Right 2 - Right to Freedom from Discrimination, Coercion, Harassment, and Exploitation.

- Right 3 - Right to Dignity and Independence.

- Right 4 - Right to Services of an Appropriate Standard.

- Right 5 - Right to Effective Communication.

\footnotetext{
${ }^{51}$ At 10.

${ }^{52}$ See Part V.

${ }^{53}$ See Parts III(B) and (C).

${ }^{54}$ Andrew Butler and Petra Butler The New Zealand Bill of Rights Act: A Commentary (LexisNexis, Wellington, 2005) at 249

${ }^{55}$ At 250.

${ }^{56}$ Health and Disability Commissioner Act 1996, s 74(1); and Health and Disability Commissioner "The Code of Rights"<www.hdc.org.nz>.

${ }^{57}$ Code of Health and Disability Services Consumers' Rights 1994, cl 1.
} 
- Right 6 - Right to be Fully Informed.

- Right 7 - Right to Make an Informed Choice and Give Informed Consent.

- Right 8 - Right to Support.

- Right 9 - Rights in Respect of Teaching or Research.

- Right 10 - Right to Complain.

The Code applies to professional volunteers and researchers through right 9, which extends the rights in the Code "to those occasions when a consumer is participating in, or it is proposed that a consumer participate in, teaching or research". There have been no Health and Disability Commissioner cases specifically concerning clinical trial participation and the Health and Disability Commissioner has not released any guidance on this matter, so it is difficult to determine how the Code of Rights applies to the unique issues arising in the case of professional volunteers. Some of the rights in the Code are, however, particularly relevant to the issues addressed below, and will therefore form part of the analysis of the problem of the professional volunteer. ${ }^{58}$

Right 7, the right to make an informed choice and give informed consent, will form the basis of much the discussion in this paper. A review of the Health and Disability Commissioner's decisions and publications shows "three essential elements" embody informed consent under the Code of Rights: "effective communication", "disclosure of adequate information", and a "voluntary decision by a competent consumer". 59 Effective communication is protected as a stand-alone right in the Code of Rights, which requires health service providers to communicate information in way that health service consumers can understand. ${ }^{60}$ Competence is expanded upon within right seven, which provides for the presumption of competence and gives guidance for cases in which a consumer may not be competent or may have diminished competence. Disclosure of adequate information and voluntary decision-making are directly relevant to the issues addressed in this paper. These elements of informed consent will therefore be considered in detail below. ${ }^{61}$

\footnotetext{
${ }^{58}$ See Part V.

${ }^{59}$ Health and Disability Commissioner Anaesthetist/Hospital (Public) (05HDC07699, 31 August 2006); Health and Disability Commissioner General Surgeon/Hospital (Private) (03HDC19128, 14 September 2004); Health and Disability Commissioner Gynaecologist/Health Centre (01HDC01835, 30 June 2003); Health and Disability Commissioner Surgeon (97HDC9370, 23 April 1999); Health and Disability Commissioner Neurosurgeon (98HDC13693, 6 December 2000); and Katharine Greig, Legal Manager "Informed consent in the Code of Health and Disability Services Consumer Rights" (presentation to the 8th Annual Medico-legal conference, 8 February 2000).

${ }^{60}$ Code of Health and Disability Services Consumers' Rights, cl 2, right 5.

${ }^{61}$ See Part V.
} 


\section{The New Zealand Bill of Rights Act 1990}

Section 10 of the New Zealand Bill of Rights Act 1990 provides every person with the right not to be subjected to medical or scientific experimentation without that person's consent (s 10). The key issues to be addressed by this paper are whether professional volunteers' apparent consent to medical experimentation constitutes legally effective consent and whether there any circumstances which justify overriding a professional volunteer's valid consent. As discussed above, ${ }^{62}$ the Code of Rights protects the right to informed consent. This right clearly applies to professional volunteers and it sets a relatively demanding and well prescribed standard as to what constitutes informed consent. ${ }^{63}$ The issue to be considered by this part of the paper is whether $\mathrm{s}$ 10 of the New Zealand Bill of Rights Act 1990 will add anything relevant to this paper's analysis of the issues presented by professional volunteers, ${ }^{64}$ which is not addressed by the Code of Rights. ${ }^{65}$

\section{Section 10 and the definition of consent}

There is a lack of useful commentary and jurisprudence on the meaning of consent for the purposes of the right not to be subjected to medical or scientific experimentation without consent. At an international level, this is likely to be a result of $\mathrm{s} 10$ being relatively unique to New Zealand (only Fiji and South Africa have comparable rights). ${ }^{66}$ Section 10 originates from, but is intentionally different to, article 7 of the International Covenant on Civil and Political Rights 1966 (ICCPR). ${ }^{67}$ Article 7 links the right against experimentation to the right to freedom from cruel, inhuman or degrading treatment by providing that: ${ }^{68}$

No one shall be subjected to torture or to cruel, inhuman or degrading treatment or punishment. In particular, no one shall be subjected without his free consent to medical or scientific experimentation.

\footnotetext{
${ }^{62}$ See Part III(B).

${ }^{63}$ PDG Skegg "Consent and Information Disclosure" in John Dawson and Nicola Peart The Law of Research: a guide (University of Otago Press, Dunedin, 2003) at 241.

${ }^{64}$ See Part V.

${ }^{65}$ Note that an analysis of the different remedies available under the Health and Disability Commissioner Act 1994 and the New Zealand Bill of Rights Act 1990 is outside the scope of this paper.

${ }^{66}$ PF v Capital and Coast District Health Board [2013] NZHC 1792 at [31]; and Butler and Butler, above n 54, at 247.

${ }^{67}$ Geoffrey Palmer “A Bill of Rights for New Zealand: A White Paper” [1984-1985] I AJHR A6 at 108.

${ }^{68}$ International Covenant on Civil and Political Rights 999 UNTS 171 (opened for signature 16 December 1966, entered into force 23 March 1976), art 7.
} 
By contrast, in the New Zealand Bill of Rights Act 1990, the right not to be subjected to torture or cruel treatment is a separate right from the right not to be subjected to medical or scientific experimentation without consent. ${ }^{69}$ According to the drafters of "A Bill of Rights For New Zealand: A White Paper" article 7 of the ICCPR linked the two rights together to ensure that only experiments which fell within cruel, inhuman or degrading treatment were forbidden. The New Zealand Bill of Rights Act 1990 was intentionally drafted to separate article 7 into two separate rights, thereby ensuring protection against all non-consensual experimentation, regardless of whether it can be characterised as cruel, degrading or inhuman. ${ }^{70}$

Very few New Zealand cases have interpreted or applied s 10, and those that have considered it have focused on the definition of scientific or medical experimentation, not consent. ${ }^{71}$ By contrast, the Code of Rights sets out comprehensive standards as to what constitutes informed consent, and there have been numerous Health and Disability Commissioner decisions which have interpreted and applied the right to informed consent. ${ }^{72}$ In the clinical research context, it would be odd if consent under s 10 were to be interpreted differently from informed consent under the Code of Rights, so that there could be consent for the purposes of s 10, but not for the purposes of the right to informed consent under the Code of Rights. Therefore, it is likely that consent for the purposes of s 10 requires fulfilment of the same essential elements as the right to informed consent under the Code of Rights - that is, effective communication, disclosure of adequate information, and a voluntary decision by a competent consumer.

\section{A purposive approach to section 10}

In Brooker $v$ Police, Thomas $\mathrm{J}$ emphasised dignity and human worth as the key values underlying the rights in the New Zealand Bill of Rights Act 1990. In particular, he noted, with respect to $\mathrm{s} 10$, that "subjecting a person to medical or scientific experimentation...without consent intrudes upon that person's freedom of will to determine his or her own fate as part of their essential dignity" ${ }^{73}$ On the basis that the rights in the New Zealand Bill of Rights Act 1990

\footnotetext{
${ }^{69}$ New Zealand Bill of Rights Act 1990, ss 9 and 10.

${ }^{70}$ Geoffrey Palmer, above n 67, at 108.

${ }^{71}$ PF v Capital and Coast District Health Board, above n 66, at [30]-[32]; McGrath v Police HC Auckland CRI2011-404-110, 20 December 2011 at [39]; $S v W$ HC Auckland CIV-2011-404-3775, 7 December 2011 at [66]; Taunoa v Attorney-General (2004) 7 HRNZ 379 at [298]-[303]; WATCH (Waikato Against Toxic and Chemical Hazards) Inc v Attorney- General HC Hamilton CIV-2003-419-1265, 29 October 2003 at [73]; Down v Van de Wetering [1999] 2 NZLR 631 at 9; Pio v Police HC Rotorua AP43/94, 4 July 1995 at 4; Pio v Police HC Rotorua AP43/94, 13 February 1995 at 4-5; and $R v$ Salmond [1992] 3 NZLR 8.

${ }^{72}$ See Part III(B).

${ }^{73}$ Brooker v Police [2007] NZSC 30, [2007] 3 NZLR 91 at [180].
} 
are derived from human dignity, in their commentary on the New Zealand Bill of Rights Act Andrew and Petra Butler take a purposive approach to the interpretation of s 10, by arguing that a person should not be able to consent to an experiment that robs them of their dignity: ${ }^{74}$

...to give full effect to the protection section 10 of the Bill of Rights Act is supposed to afford, a paternalistic approach should be taken and the concept of consent should be interpreted as not including consent to an inhuman, cruel or degrading medical or scientific experimentation. A free and democratic society cannot allow its members to become the object of such medical experiments since that robs the person of his or her dignity. As the Preamble of the ICCPR acknowledges dignity is the inherent human right from which all other rights are derived. A state which would allow its members to alienate their right to dignity would be at risk of not protecting or taking seriously other rights.

With respect, this is a difficult argument to apply in practice. The New Zealand Bill of Rights Act 1990 does not include a free-standing right to dignity, but it does include a right not to be subjected to medical or scientific experimentation without consent. As explained above, ${ }^{75}$ the drafting history of s 10 illustrates that consent is fundamental to this right. In this context, in the author's opinion, s 10 should be interpreted according to its plain meaning so that legally effective consent to medical or scientific experimentation is sufficient to ensure that $\mathrm{s} 10$ is not breached. Therefore, as long as a professional volunteer gives valid consent to participate in a clinical trial (according to the interpretation advanced above), ${ }^{76}$ there can be no breach of $\mathrm{s} 10$. This is consistent with the dicta cited from Thomas $\mathrm{J}$ above, which indicates that in the context of s 10, if autonomy is overridden, so is dignity. This is also consistent with the position of medical ethics, which considers respect for autonomy (which forms the primary justification for informed consent $)^{77}$ to be a "component of respect for human dignity". ${ }^{78}$

\section{The application of the New Zealand Bill of Rights Act 1990 to the Ethical Guidelines}

Given the discussion above, s 10 does not appear to add any requirements relevant to professional volunteers' consent to medical experimentation that are not addressed by the comprehensive provisions of the Code of Rights. Nevertheless, this part of the paper will argue

\footnotetext{
${ }^{74}$ Butler and Butler, above $\mathrm{n} 54$, at 264.

${ }^{75}$ See Part III(C)(1).

${ }^{76}$ See Part III(C)(1).

${ }^{77}$ Natalie Abrams and Michael D Buckner Medical Ethics: A Clinical Textbook, and Reference for the Health Care Professions (The MIT Press, United States of America, 1984) at 4.

${ }^{78}$ Kerry J Breen and others Good Medical Practice: Professionalism, Ethics and Law (Cambridge University Press, New York, 2010) at 4.
} 
that s 10 is still relevant to the discussion in this paper by virtue of s 3 of the New Zealand Bill of Rights Act 1990, which provides for the Act's application:

This Bill of Rights applies only to acts done-

(a) by the legislative, executive, or judicial branches of the Government of New Zealand; or

(b) by any person or body in the performance of any public function, power, or duty conferred or imposed on that person or body by or pursuant to law.

The Ethical Guidelines were made by the National Ethics Advisory Committee, pursuant to the New Zealand Public Health and Disability Act $2000 .{ }^{79}$ If this function falls within the scope of $\mathrm{s}$ 3, by law the Ethical Guidelines will need to be evaluated for consistency with s 10 of the New Zealand Bill of Rights Act 1990. By contrast, there is no legal requirement that the Ethical Guidelines must be consistent with the Code of Rights.

The act of the National Ethics Advisory Committee determining the Ethical Guidelines could potentially fall within paragraph (a) of s 3, as an act done by the executive, or paragraph (b) of $\mathrm{s}$ 3 , as a public function imposed on the Committee by law. There is limited case law on the definition of "executive" for the purposes of s $3 .{ }^{80}$ Given the relatively wide scope of paragraph (b), the practice of the courts has been to apply this paragraph and avoid a definition of “executive". In Federated Farmers $v$ New Zealand Post, for example, rather than holding New Zealand Post (a state owned enterprise) to be part of the executive, McGechan $\mathrm{J}$ reasoned that "the question more naturally arises under s 3(b)" ${ }^{81}$ The National Ethics Advisory Committee is a ministerial advisory committee established by the Minister of Health under s 16 of the New Zealand Public Health and Disability Act 2000. ${ }^{82}$ The Committee, which is accountable to the Minister of Health, ${ }^{83}$ could potentially fall within the meaning of executive, but given that the courts' default approach appears to be to apply s 3(b) instead, it is more likely that s 3 will be engaged through s 3(b). The function of the National Ethics Advisory Committee in determining the Ethical Guidelines undoubtedly falls within paragraph (b). This function is imposed on the National Ethics Advisory Committee by law because it is a function required of the Committee under the New Zealand Public Health and Disability Act $2000 .{ }^{84}$ With regards to whether the

\footnotetext{
${ }^{79}$ New Zealand Public Health and Disability Act, s 16(2).

${ }^{80}$ See generally Andrew Butler and Petra Butler, above n 54, at 91-92; and Laws of New Zealand Human Rights (online ed) at [13].

${ }^{81}$ Federated Farmers of New Zealand Inc v New Zealand Post Ltd (1992) [1990-1992] 3 NZBORR 339.

${ }^{82}$ National Ethics Advisory Committee Terms of Reference for the National Ethics Advisory Committee (February 2012) at 1.

${ }^{83}$ At 1.

${ }^{84}$ New Zealand Public Health and Disability Act, s 16(2); and National Ethics Advisory Committee, above n 7, at 1.
} 
function is "public", in Federated Farmers $v$ New Zealand Post McGechan J found that mail handling fell within the definition of "public function" because it "is carried out for the public, in the public interest, and moreover by a company which...is wholly owned and ultimately controlled by the Crown". ${ }^{85}$ In Ransfield $v$ The Radio Network Ltd, Randerson J put forward "a range of possible considerations" for determining whether a function is public, including whether the source of the function is statutory, the extent and nature of any governmental control of the entity and whether the function is being exercised in the broader public interest. ${ }^{86}$ Applying the reasoning of these cases, the function of the National Ethics Advisory Committee, in determining the Ethical Guidelines, must be a public function. The National Ethics Advisory Committee is a statutory body, accountable to the Ministry of Health and its statutory function of determining "nationally consistent ethical standards across the health sector" is for the public and in the public interest. ${ }^{87}$

The Ethical Guidelines must therefore be consistent with the New Zealand Bill of Rights Act 1990. Accordingly, the recommendations in this paper proposing amendments to the Ethical Guidelines will need to be evaluated for consistency with the New Zealand Bill of Rights Act 1990, in particular, the right not to be subjected to medical experimentation without consent.

\section{Ethical Decision-Making and the Dominance of Autonomy}

Before this paper considers the problem of the professional volunteer and proposals for reform, it is helpful to first introduce the general ethical framework for decision-making in medical practice. This will influence the application and development of regulation in this area.

\section{A Ethical Regulation of Clinical Research}

Most professions have codes of ethical conduct, setting standards of proper behaviour for people in that profession. ${ }^{88}$ For medical practitioners in particular, medical ethics is a highly developed discipline which permeates all areas of clinical practice. Medical ethics provides a set of values and principles to guide and justify the action (or inaction) of practitioners. ${ }^{89}$ It is important to note that while medical ethics can, and does, influence the law and the interpretation of the law, medical ethics and the law (and in particular, the rights protected by law) are not the same

\footnotetext{
${ }^{85}$ Federated Farmers of New Zealand Inc v New Zealand Post Ltd, above $\mathrm{n} 81$.

${ }^{86}$ Ransfield $v$ The Radio Network Ltd [2005] 1 NZLR 233 at [69] - [70].

${ }^{87}$ New Zealand Public Health and Disability Act, s 16(2).

${ }^{88}$ Breen, above $\mathrm{n} 78$, at 9 .

${ }^{89}$ At 2.
} 
thing. ${ }^{90}$ Clinical research (which forms a discipline within medical practice) has traditionally been largely regulated by ethical codes, and despite the general increase in legislative regulation of medical practice, this continues to be the case. Numerous ethical codes for human experimentation, both national and international, have been developed over the last 60 years. $^{91}$ The Nuremberg Code and the Declaration of Helsinki are probably the most cited international instruments. The Nuremberg Code was issued in 1947, ${ }^{92}$ in response to war crimes and crimes against humanity committed by Nazi physicians throughout world war two. The Code comes directly from the judgment of the Nuremberg trials, which sets out ten principles for ethical human experimentation. ${ }^{93}$ The Declaration of Helsinki, which was adopted by the World Medical Association in 1964, provides a more up-to-date international code, having been most recently amended in 2008. ${ }^{94}$ Many jurisdictions, including New Zealand, ${ }^{95}$ have incorporated the principles of these international codes into their own domestic standards. ${ }^{96}$ As already discussed, in New Zealand clinical research is largely governed by the Ethical Guidelines. ${ }^{97}$

\section{B Principles for Ethical Decision-Making}

The ethical principles of autonomy, beneficence, non-maleficence and justice provide a contemporary framework for ethical decision-making in medical practice. ${ }^{98}$ While these principles are applicable to medical ethics generally, they are particularly relevant to clinical research ethics. The principles originate from the Belmont Report, ${ }^{99}$ a 1978 report from the United States National Commission for the Protection of Human Subjects of Biomedical and Behavioural Research which provides basic moral principles for conducting research with

\footnotetext{
90 Alastair Campbell, Grant Gillett and Gareth Jones Medical Ethics (3ed, Oxford University Press, Melbourne, 2001) at 267.

91 Ezekiel J Emanuel, David Wendler and Christine Grady "An Ethical Framework for Biomedical Research" in Ezekiel J Emanuel and others The Oxford Textbook of Clinical Research Ethics (Oxford University Press, New York, 2008) at 123.

92 At 124.

${ }^{93}$ George J Annas and Michael A Grodin The Nazi Doctors and the Nuremburg Code: Human Rights in Human Experimentation (Oxford University Press, New York, 1992) at 3-4.

94 World Medical Association Declaration of Helsinki, above n 1.

${ }^{95}$ National Ethics Advisory Committee, above n 7, at 1.

${ }^{96}$ Emanuel, Wendler and Grady, above n 91, at 124.

${ }^{97}$ See Part III(A).

98 Breen, above n 78, at 4; Campbell, Gillett and Jones, above n 90, at 12-14; JK Mason and GT Laurie Mason \& McCall Smith's Law \& Medical Ethics (9ed, Oxford University Press, 2012) at 6; and Alan Wetheimer "Exploitation in Clinical Research" in Ezekiel J Emanuel and others The Oxford Textbook of Clinical Research Ethics (Oxford University Press, New York, 2008) at 201.

${ }^{99}$ Breen, above $\mathrm{n} 78$, at 4 .
} 
humans. ${ }^{100}$ Further, the principles have been directly incorporated into the Ethical Guidelines as underlying ethical considerations. ${ }^{101}$ This part of the paper will focus on autonomy, because this ethical principle, and the tension between it and other interests, forms the underlying theme of this paper.

\section{The Dominance of Autonomy}

The principle of autonomy in medical ethics encompasses the notion that, as independent moral agents, patients (or more generally consumers of health services) are the best judge of what is in their own interests and should be able to make their own decisions about what will happen to their bodies. ${ }^{102}$ Respect for autonomy requires health service providers to respect these decisions, ${ }^{103}$ notwithstanding that a patient may choose a greater risk for himself/herself than others may choose for him/her. ${ }^{104}$

Respect for autonomy has become the overriding ethical principle of good medical practice. ${ }^{105}$ It has "dominated the control of medical practice [over] the last-half century" and is "by far the most significant value to have influenced the evolution of contemporary medical law". ${ }^{106}$ The reign of autonomy has resulted in a wide spread rejection of the historic notion of medical paternalism, in which the "doctor always knew best" and patients were given limited information, and had little control over, their treatment. ${ }^{107}$ Autonomy is primarily recognised by the requirement that health consumers must give informed consent to health services. Health service providers are said to have a moral duty to obtain informed consent by virtue of their patient's autonomous status. ${ }^{108}$ In New Zealand, informed consent is protected as a right under the Code of Rights. ${ }^{109}$ As we have seen, the Code of Rights applies to all consumers of health and disability services, including professional volunteers. ${ }^{110}$ Informed consent features as the first principle in the Nuremberg Code and forms much of the focus of the Declaration of

\footnotetext{
100 The National Commission for the Protection of Human Subjects of Biomedical and Behavioural Research Ethical Principles and Guidelines for the Protection of Human Subjects of Research (United States Department of Health and Human Services, 1978).

${ }^{101}$ Note that autonomy forms a component of the ethical principle "respect for persons", see Part III(A).

102 Mason and Laurie, above $\mathrm{n} 98$, at 5.

103 Breen, above n 78, at 4.

${ }^{104}$ Abrams and Buckner, above $\mathrm{n} 77$, at 3.

105 Breen, above n 78, at 13.

${ }^{106}$ Mason and Laurie, above n 98, at 8.

107 At 8 .

${ }^{108}$ Abrams and Buckner, above $\mathrm{n} 77$, at 4.

${ }^{109}$ Code of Health and Disability Services Consumers' Rights, cl 2, right.

110 See Part III(B).
} 
Helsinki. ${ }^{111}$ The Ethical Guidelines provide extensive guidance on informed consent, ${ }^{112}$ and the right against medical experimentation in the New Zealand Bill of Rights Act 1990 is subject to consent. $^{113}$ Informed consent is therefore not only an important right in medical practice generally, but it also forms a dominant requirement of clinical research ethics. It is important to note that informed consent in research does not just protect against research without consent, it also empowers research volunteers to decide which trials they want to participate in and what level of risk they are willing to accept. By empowering volunteers to decide if and how they will get involved in research, informed consent respects individual autonomy. ${ }^{114}$

In New Zealand, autonomy is particularly dominant because of the Cartwright Inquiry which, in part, blamed the paternalistic practices of health professionals for the "Unfortunate Experiment at National Women's" Hospital. ${ }^{115}$ Informed consent and patient rights were central issues of the Cartwright Inquiry, which is described as the "watershed event in terms of doctors' attitudes to patients in New Zealand". 116 The Cartwright Report which resulted from this Inquiry prompted the enactment of the Health and Disability Commissioner Act 1994, under which the Code of Rights is made. ${ }^{117}$

\section{Balancing Autonomy and Other Interests}

Despite its dominance, however, autonomy is not the only interest which regulation seeks to further. There are numerous examples of the law overriding individual autonomy, by limiting the power to give legally effective consent, which fall within the realm of medical ethics. ${ }^{118}$ For example, the Crimes Act 1961 specifically disavows the right to consent to the infliction of one's

${ }^{111}$ Trials of War Criminals Before the Nuremberg Military Tribunal Under Control Council Law 10 (1949) 2 Washington DC, United States Government Printing Office at 181-182 [The Nuremberg Code] available at United States Department of Health and Human Services "The Nuremberg Code" <www.hhs.govt>; and World Medical Association Declaration of Helsinki, above n 1, at B(22), B(24)-(29).

${ }^{112}$ National Ethics Advisory Committee, above n 7, at 20-23.

${ }^{113}$ New Zealand Bill of Rights Act, s 10.

${ }^{114}$ Emanuel, Wendler and Grady, above n 91, at 130.

${ }^{115}$ Silvia Cartwright The Report of the Committee of Inquiry into allegations concerning the treatment of Cervical Cancer at National Women's Hospital and into other related matters 1988 (Government Printing Office, ISBN 0473-00664-2, July 1988) at 129; and see generally Sandra Coney and Phillida Bunkle "An Unfortunate Experiment at National Women's" Metro (New Zealand, June 1987).

116 Ron Paterson Health and Disability Commissioner "Address to the $12^{\text {th }}$ Annual Release of the Cartwright Report" (presentation at Women's Health Action's function, 4 August 2000).

${ }^{117}$ Health and Disability Commissioner "History" < www.hdc.org.nz> .

${ }^{118}$ PDG Skegg and Ron Paterson Medical Law in New Zealand (Brookers Ltd, Wellington, 2006) at 161. 
own death and precludes consent as a defence to female genital mutilation. ${ }^{119}$ The Human Assisted Reproductive Technology Act 2004 prohibits and criminalises the commercial supply of human embryos or gametes and commercial surrogacy arrangements, ${ }^{120}$ and the Human Tissue Act 2008 generally prohibits and criminalises trading in human tissue. ${ }^{121}$

This paper illustrates the tension between autonomy and other underlying ethical and regulatory objectives, in the context of the regulation of professional volunteers. There are three central issues to consider. Firstly, how can we regulate financial compensation to ensure that volunteers are neither unduly induced into volunteering, and therefore unable to give informed consent, nor exploited? ${ }^{122}$ Secondly, should volunteers be able to consent to expose themselves to compounded safety risks? ${ }^{123}$ Thirdly, should professional volunteers be able to consent to their commodification and dehumanisation? ${ }^{124}$

\section{$V$ The Problem of the Professional Volunteer}

In his book "The Professional Guinea Pig", Abadie raises a number of objections to the treatment of professional guinea pigs in the United States. In particular, he is concerned by the exploitation and dehumanisation of volunteers, the exposure of volunteers to the "cumulative result of drug interactions resulting from years of trial participation", and the pharmaceutical industry's denial of their commodification. ${ }^{125}$ The following paragraphs will argue that these issues also arise in New Zealand. Recommendations to amend the Ethical Guidelines to address these issues will be advanced. Where relevant, the recommendations will be analysed for consistency with the Code of Rights and s 10 of the New Zealand Bill of Rights Act 1990.

\section{A Exploitation}

Part 1 of this section will argue that the Ethical Guidelines, by limiting the value of financial compensation that can be provided to volunteers for participating in clinical trials, allow, and in some cases may require, clinical trials to exploit professional volunteers (the issue). The issue of exploitation in research is often raised in relation to enrolling the poor in clinical trials, and in

\footnotetext{
${ }^{119}$ Crimes Act 1961, ss 63 and 204A(6).

${ }^{120}$ Human Assisted Reproductive Technology Act 2004, s 13-14.

${ }^{121}$ Human Tissue Act 2008, s 56.

122 See Part V(A).

${ }^{123}$ See Part V(B).

${ }^{124}$ See Part V(C).

${ }^{125}$ Abadie, above n 5, at 157-158.
} 
this context has been defined to mean a situation in which "A takes unfair advantage of B". ${ }^{126}$ The argument here is that a requirement limiting compensation is unfair, given the significant safety risks volunteers may be exposed to, ${ }^{127}$ and takes advantage of professional volunteers' financial need. Put another way, the Ethical Guidelines allow for an "unfair distribution of harm and benefit between the two parties". ${ }^{128}$ Researchers get the benefit of only having to pay limited compensation for volunteers' invaluable role in research, while volunteers are paid a marginal amount for their exposure to considerable risks.

Part 2 of this section will put forward and critique two proposals for addressing this issue of exploitation.

\section{$1 \quad$ Issue}

(a) Professional volunteers are likely to be poor

Professional volunteers repeatedly participate in clinical trials, primarily or solely because of the financial compensation provided for participation. They have traditionally been broken into three groups: students, low-income unskilled workers and those who participate as means of maintaining a marginal lifestyle. ${ }^{129}$ The common feature of these groups is that they are all likely to be in need of money. While there is no reliable data on the demographics of Phase I trial volunteers, Abadie found that most of the volunteers he interviewed who regularly volunteered in trials were "poor and relatively uneducated". ${ }^{130}$ These findings are consistent with a common sense approach. Participation in Phase I clinical trials is likely to be time consuming, so those with reliable full time employment are unlikely to be able to commit to it. Further, as we shall see, volunteers in Phase I trials are exposed to considerable safety risks, ${ }^{131}$ and it seems unlikely that anyone would be willing to expose themselves to such risks unless they needed the money. This is consistent with the findings of the Belmont Report (introduced in Part IV(B)) which recognised the risk of economically disadvantaged populations being targeted by research "owing to their ready availability" and "socioeconomic condition". ${ }^{132}$ Researchers appear to be well aware of this and are not shy of targeting the economic underclass. For example, in the

\footnotetext{
126 Wertheimer, above n 98, at 202.

127 See Part V(B).

128 Dickert and Grady, above n 2, at 391.

129 Sheldon Zink "Maybe We Should Pay Them More” (2001) 1(2) Am J Bioethics 88 at 88.

${ }^{130}$ Abadie, above n 4, at 12.

${ }^{131}$ See Part V(B).

132 The National Commission for the Protection of Human Subjects of Biomedical and Behavioural Research, above n 100, at Part C(3).
} 
United Kingdom, "The Big Issue" magazine, which is sold by homeless people, often includes advertisements for clinical research volunteers. ${ }^{133}$ In New Zealand, it is not uncommon for clinical research to target university students. ${ }^{134}$

Targeting the poor in Phase I trials is an issue in itself. It means that poor individuals are overrepresented in research and that "an already disadvantaged segment of the population could bear a disproportionate share of the research burden". ${ }^{135}$ This violates the principle of justice, an underlying consideration of the Ethical Guidelines, which requires that, "within a population, there is a fair distribution of the benefits and burdens of participation in a study". ${ }^{136}$ In the United States, federal regulations recognise "economically disadvantaged persons" as a "vulnerable population" and require research involving such persons to ensure that their selection is "equitable" and that "additional safeguards" are in place to protect their "rights and welfare." 137 Although these protections have been criticised as being too vague, ${ }^{138}$ the United States still offers better protection for the economically disadvantaged in research than New Zealand. The New Zealand Ethical Guidelines do not even expressly recognise the economically disadvantaged as falling within the category of "vulnerable people". ${ }^{139}$

(b) The Ethical Guidelines limit financial compensation

The financial compensation provided by clinical trials to volunteers must be disclosed to an ethics committee as part of the ethical approval process, ${ }^{140}$ so that it can be reviewed for consistency with the Ethical Guidelines. ${ }^{141}$ The Ethical Guidelines recognise that financial compensation (or "inducements") can normally be ethically acceptable, but will be unacceptable if it amounts to "undue influence". ${ }^{142}$ Undue influence is not expressly defined, but it seems to mean inducing a volunteer to participate against their better judgment, so that their decision is not voluntary and there is no informed consent. ${ }^{143}$ In stating that the "risks involved in

\footnotetext{
${ }^{133}$ Pamela R Ferguson “Clinical Trials and Healthy Volunteers” (2008) 16(1) Med Law Rev 23 at 30.

${ }^{134}$ Auckland Clinical Studies "About ACS"<www.clinicalstudies.co.nz>.

135 Dickert and Grady, above n 2, at 390.

136 See Part III(A).

${ }^{137}$ Code of Federal Regulations, Part 46 (Protection of Human Subjects) $\$ 46.111$, (a)(3) and (b).

${ }^{138}$ Leslie A Meltzer and James F Childress "What is Fair Participant Selection" in Ezekiel J Emanuel and others The Oxford Textbook of Clinical Research Ethics (Oxford University Press, New York, 2008) at 382.

${ }^{139}$ National Ethics Advisory Committee, above n 7, at 14-15.

140 At 26.

${ }^{141}$ See Part II(C) for an outline of the ethical approval process.

${ }^{142}$ National Ethics Advisory Committee, above n 7, at 25.

${ }^{143}$ At 20 and 26.
} 
participation should be acceptable to participants even in the absence of any inducement", ${ }^{144}$ the Ethical Guidelines indicate that if a volunteer is solely motivated by an inducement there will be undue influence. The Ethical Guidelines accordingly correlate undue influence with the value of the inducement, ${ }^{145}$ and only recognise payments of limited value, such as reimbursements of expenses (like travel costs), payment in recognition of time/inconvenience/discomfort or koha, as appropriate payments. ${ }^{146}$ There is therefore no requirement that volunteers must be paid at least minimum wage, and the general approach of the Ethical Guidelines suggests that it may be appropriate to pay volunteers less than minimum wage.

(c) Limited compensation takes advantage of professional volunteers' financial need

The approach of the Ethical Guidelines to financial compensation does not accord with the reality of professional trial participation. Professional volunteers are not akin to other types of volunteers because they are primarily, if not solely, motivated to volunteer by financial reasons. Risks involved in participation are not acceptable to them in the absence of financial inducements, because the only reason for volunteering, and therefore accepting the risks, are the financial inducements. This problem is not solved by limiting the value of compensation that can be provided, because professional volunteers will still volunteer for the financial compensation, even if it is limited. As Abadie explains: ${ }^{147}$

...a sum of money that the wealthy can easily resist may be very tempting for poorer people.

Keeping payments low, however, seems unfair to the poor, who submit to trials precisely because they need the money. And whether or not such people are being unduly induced, the larger question is whether they are being exploited.

It follows that the effect of keeping compensation low is that those who end up volunteering are those who are most in need of money - those who are willing to expose themselves to safety risks for less than minimum wage. This is illustrated by the recruitment practice of pharmaceutical company Eli Lilly, which is infamous for targeting homeless alcoholics by providing the lowest compensation in the industry. ${ }^{148}$ The Ethical Guidelines, therefore, in

\footnotetext{
144 At 26.

145 At 26.

146 At 26.

147 Elliott Carl and Roberto Abadie "Exploiting a Research Underclass in Phase I Clinical Trials" (2008) 358(22) NEJM 2316 at 2316.

148 Laurie P Cohen "Stuck for money: To screen new drugs for safety, Lilly pays homeless alcoholics" (14 November 1996) WSJ (Eastern Edition) A1.
} 
encouraging researchers to limit financial inducements, allow research to exploit professional volunteers' need for money.

\section{Proposals for reform}

The current regulatory framework for clinical research does not address the issue of exploitation of professional volunteers. While the Code of Rights does protect the right to be free from exploitation, ${ }^{149}$ the payment of limited compensation to professional volunteers is unlikely to be a breach of the Code of Rights. All obligations under the Code of Rights are subject to a standard

of reasonableness. ${ }^{150}$ It would be very difficult to argue that researchers are acting unreasonably by following the Ethical Guidelines, which they must comply with under right 4 of the Code of Rights.

This part of the paper will put forward and critique two proposals for addressing the issue of exploitation. Paragraph (a) will evaluate the option of prohibiting financial compensation and paragraph (b) will argue that the Ethical Guidelines should be amended to require financial payment to be fair.

(a) Prohibit financial compensation

If financial compensation for volunteering in clinical trials was prohibited, there would be no risk of volunteers being exploited or unduly influenced by financial compensation. Such a proposal, however appealing in theory, is probably unrealistic in practice. Prohibiting financial compensation would have the effect of prohibiting professional volunteering, and as Abadie explains, relying only on altruistic volunteers is problematic: ${ }^{151}$

Maintaining phase I trials but ending financial compensation so that all volunteers were altruistic would not work either. This solution might be appealing but would considerably slow down or stop drug development altogether. After all, asking citizens to place themselves in harm's way by taking drugs they do not need to assess their toxicity might be quite a duty call for most. Not to mention that even very altruistic subjects might be hesitant to volunteer to test drugs for a pharmaceutical industry that they might perceive as not trustworthy. Altruism would also deprive poor research subjects of much needed income.

\footnotetext{
${ }^{149}$ Code of Health and Disability Services Consumers' Rights, cl 2, right 2.

${ }^{150}$ Code of Health and Disability Services Consumers' Rights, cl 3.

${ }^{151}$ Abadie, above n 4, at 164.
} 
Abadie's comments are made with respect to professional volunteers in the United States, but the author suspects that they also apply to New Zealand. Professional volunteers are likely to be a necessity for Phase I research, so a prohibition of financial compensation is likely to impede clinical research in New Zealand. However, because there is limited data available on professional volunteers in New Zealand, ${ }^{152}$ this paper recommends that research should be conducted to determine whether professional volunteers are necessary for the viability of the clinical trial industry in New Zealand.

\section{(b) Fair payment}

The obvious solution to remedy the unfair advantage taken of professional volunteers would be to pay them more. ${ }^{153}$ An alternative proposal to address the issue of exploitation is therefore to ensure that professional volunteers are paid fairly. Abadie advocates for workers' rights for volunteers, akin to the rights of other workers in risky occupations. ${ }^{154}$ In the author's opinion, this would be unnecessary in the New Zealand context. As discussed in Part II(B) of this paper, the number of professional volunteers in New Zealand is likely to be small. Further, if professional volunteers have any issues with their "working conditions" they should be able to get redress under the Code of Rights. The Code provides for a comprehensive set of health consumer rights, which are supported by the Health and Disability Commissioner Advocacy system. Rights such as the right to be treated with respect, the right to freedom from discrimination and harassment and the right to services of an appropriate standard should be wide enough to ensure that clinical trial conditions are adequate. ${ }^{155}$

A better solution would be to amend the Ethical Guidelines to expressly acknowledge that volunteers may be motivated to volunteer by financial reasons and to provide that financial payment must be fair. It would then fall to the ethics committee to determine, as part of the ethical approval process, whether the payment offered by a particular trial is fair in the circumstances. There are varying degrees of risk involved in Phase I clinical trials, which could test anything from a low risk anti-fungal cream, for example, to the high risk monoclonal antibody which was tested in the TGN1412 trial. ${ }^{156}$ Amongst other factors, such as time and the number of tests required, the ethics committee could take into account the level of risk involved in the trial, and evaluate payment accordingly. Paying trial participants according to risk, while a

\footnotetext{
152 See Part II(B).

${ }^{153}$ Dickert and Grady, above n 2, at 391.

154 Abadie, above n 4, at 165-166.

155 See Part III(B).

${ }^{156}$ See Part V(B).
} 
controversial proposition, is not without support. For example, Jerry Menikoff from the University of Kansas rejects the rationale for compensation that our Ethical Guidelines are based on - that compensation is for time and inconvenience - on the basis that "risk assumption" is a volunteer's true contribution: ${ }^{157}$

\begin{abstract}
After all, in other areas of society we do expect compensation to vary based on the amount of risk someone assumes. A fireman and a person who stacks boxes in a warehouse may perform similar physical tasks, yet the fireman gets paid far more due to the job risks. A research study involving administration of a new drug to a healthy subject may involve only two hours of a subject's time, but the time involvement is a poor measure of the services provided by the subject. It would be a misleading comparison to suggest that this was the equivalent of working two hours behind the cash register at McDonald's. It is equally misleading to say that a subject who swallows a well-studied medicine is performing a similar function to someone who swallows a pill in a Phase I study.
\end{abstract}

This proposal will not stop clinical trials targeting poorer groups, because only those in need of money will volunteer, but it should stop clinical trials exploiting poor volunteers in the sense that they will be paid fair compensation for the risks they endure. Rather than adopting a paternalistic approach aiming to protect volunteers from financial inducements, this proposal acknowledges that volunteers provide a valuable service which is worthy of financial recognition. ${ }^{158}$

Amending the Ethical Guidelines to include the requirement that volunteers be paid fair compensation, would require removal of the current limitations on the value of payment. This raises the issue of undue influence, illustrating the tension between exploitation and undue influence, ${ }^{159}$ which the Ethical Guidelines attempt to avoid by limiting payment. Undue influence is the major concern raised by ethicists in relation to the contentious issue of providing payment to research volunteers. ${ }^{160}$ Ethicists argue that volunteers can be unduly influenced by payment in two ways. Firstly, payment may cause a volunteer to ignore the risks of participating in a trial. ${ }^{161}$ In New Zealand, this concern can be rejected as argument for limiting financial compensation on the basis that it is already adequately dealt with by the right to informed consent under the Code of Rights. As we shall see in Part V(B), informed consent requires a volunteer to be fully informed of the risks of a study. This means that it is the responsibility of

157 Jerry Menikoff “Just Compensation: Paying Research Subjects Relative to the Risks They Bear” (2001) 1(2) AJOB 56 at 56.

${ }^{158}$ Dickert and Grady, above n 2, at 391.

159 At 391.

160 At 389.

${ }^{161}$ At 389. 
the researcher to ensure, on a case-by-case basis, that volunteers do not ignore the risks of research and to prohibit volunteers from participating in trials if they do. The second concern advanced in relation to payment goes to the voluntariness of the decision to participate in research. Ethicists speak of "large incentives controlling individuals' decisions in a way that is morally objectionable", ${ }^{162}$ or financial payment "inducing prospective subjects to consent to participate in the research against their better judgment". ${ }^{163}$ While it is possible that financial payments may, in some cases, affect the voluntariness of a volunteer's decision in this way, the more likely scenario is that a volunteer will be legitimately and voluntarily motivated to participate by financial compensation. This distinction is well articulated by Alan Wertheimer in his commentary on exploitation in clinical research: ${ }^{164}$

We must be careful to properly interpret the phrase "against their better judgment". It is important to distinguish between two claims:

1) The inducements constitute a seductive offer that motivates people to consent to participate when doing so does not advance their interests

2) Given the people's objective circumstance, the inducements make it rational for them to participate.

Note that in (2) the inducements are large enough to render participation compatible with the participant's better judgment given the objective conditions in which they find themselves, although participation might have been against their better judgment in the absence of those inducements or under different conditions. The real tragedy of poverty is not that (1) is often true, but that (2) is often true.

Given this distinction, concerns about financial inducements amounting to undue influence are also better dealt with by the right to informed consent under the Code of Rights, rather than a blanket rule limiting payment (which exploits those who are legitimately motivated by financial inducements). Informed consent already requires consent to be "voluntary" or "freely given", ${ }^{6}$ so if financial payment compromises a volunteer's ability to give free consent there will be a breach of the right to informed consent (and, given the analysis in Part III(C)(1), a breach of the right not to be subjected to medical experimentation without consent under the New Zealand Bill of Rights Act 1990). In individual cases, financial compensation may induce a volunteer to

\footnotetext{
162 At 389.

${ }^{163}$ Wetheimer, above n 98, at 208.

164 At 208.

${ }^{165}$ See Part III(B).
} 
participate in a trial against their better judgement, rather than according to it. Such cases are, however, likely to be a "rare occurrence". ${ }^{166}$ They are therefore better dealt with on a case-bycase basis by the right to informed consent, and, by the researcher who has the benefit of evaluating the volunteer and the expertise to determine whether there is informed consent.

This proposal ensures that professional volunteers are not exploited, but still requires researchers to comply with the requirements of informed consent. It is therefore consistent with the right not to be subjected to medical experimentation without consent, ${ }^{167}$ the right to informed consent and the right to freedom from exploitation. ${ }^{168}$ Although the Health and Disability Commissioner jurisprudence already provides extensive guidance on informed consent, if this proposal were to be adopted, specific guidance in the Ethical Guidelines as to how financial compensation may affect the voluntariness of consent may be necessary to ensure that researchers comply with their obligations under the Code of Rights and New Zealand Bill of Rights Act 1990.

By recognising that volunteers can have legitimate financial motivations for enrolling in a trial, rather than trying to protect them from such motivations, this proposal advances the underlying ethical objective of autonomy. ${ }^{169}$ Further, because it is likely that more people will volunteer in clinical trials if the financial payment is fair, thereby more widely distributing the risks of trial participation, this proposal advances the underlying ethical consideration of justice. ${ }^{170}$

\section{B Unregulated Compounded Risks}

Part 1 of this section will argue that professional volunteers are exposed to unregulated compounded risks (issue one), and that because the Ethical Guidelines fail to acknowledge the existence of repeat volunteers, it is unlikely that volunteers are properly informed of these risks. It will therefore be concluded that, in practice, researchers are likely to be in breach of the right to informed consent and the right not to be subjected to medical experimentation without consent (issue two).

Part 2 of the section will put forward and critique two proposals to address these issues. The analysis will include a discussion of whether regulation should prevent volunteers from choosing to expose themselves to avoidable risks.

\footnotetext{
166 Dickert and Grady, above n 2, at 390.

${ }^{167}$ New Zealand Bill of Rights Act, s 10.

${ }^{168}$ Code of Health and Disability Services Consumers' Rights, cl 2, rights 2 and 7.

${ }^{169}$ Dickert and Grady, above n 2, at 389.

170 See Part III(A).
} 


\section{$1 \quad$ Issues}

(a) Issue one - exposure to unregulated compounded risks

Participation in a Phase I clinical trial exposes a volunteer to uncertain and potentially life threatening adverse reactions. Risks to volunteers are based on pre-clinical data resulting from animal testing, ${ }^{171}$ but because the trial drug has never before been tested in human beings it can be difficult to predict how it will behave in humans. ${ }^{172} \mathrm{~A}$ harrowing example of this is the infamous TGN1412 study conducted in London in 2006. Six volunteers in this Phase I study suffered systemic organ failure, despite being administered doses of the experimental drug which were allegedly 500 times lower than the dose estimated as safe from pre-clinical studies. ${ }^{173}$ An investigation led by the United Kingdom Medicines and Healthcare Products Regulatory Agency concluded that the pre-clinical testing had been adequate and the adverse reactions were caused by "an unpredicted biological action of the drug in humans". ${ }^{174}$

Safety risks are an inevitable part of participation in a clinical trial. This is particularly so for Phase I trials, the very purpose of which is to test drug safety. ${ }^{175}$ But in the case of professional volunteers, the safety risks of participation are even greater, because repeat participation compounds risk. As Jaillon observes: ${ }^{176}$

...multiplying the number of investigational drugs absorbed by a subject over a relatively short period of time can considerably increase the risk of drug reaction and of severe adverse drug reaction.

There is nothing to prevent a professional volunteer from choosing to expose themselves to these compounded risks. Risk assessment for clinical trials is conducted at the approval stage, by the Health Research Council of New Zealand's Standing Committee on Therapeutic Trials. The

\footnotetext{
${ }^{171}$ National Ethics Advisory Committee, above n 7, at 18.

172 Pamela R Ferguson "Clinical Trials and Healthy Volunteers" (2008) 16 Med Law Rev 23 at 25.

${ }^{173}$ Giuseppe Pasqualetti and others "Healthy volunteers and early phases of clinical experimentation" (2010) 66 Eur J Clin Pharmacol 647 at 651.

174 Medicines and Healthcare Products Regulatory Agency (UK) Investigations into Adverse Incidents during Clinical Trials of TGN1412 (May 2006) at [6].

${ }^{175}$ Abadie, above n 4, at 164.

176 Jaillon P "Healthy volunteers' data bank: Where and how?" (1990) 4(2) Fundam Clin Pharmacol 177S at 181S cited in CL Tishler and S Bartholomae "Repeat participation among normal healthy research volunteers: professional guinea pigs in clinical trials?” (2003) 46(4) Perspect Biol Med 508 at 514.
} 
Standing Committee is only responsible for conducting a "scientific assessment" of the individual trial in question, and therefore does not have to consider the effects of long term participation in numerous trials on individual volunteers. ${ }^{177}$ Furthermore, the Ethical Guidelines do not prevent repeat trial participation, or limit the number of trials a volunteer can participate in. There is therefore no mandatory risk assessment of these compounded risks, which are left unregulated. In addition, the absence of a centralised database of trial participants makes it difficult to track the side effects of repeat trial participation and, as Abadie argues, the pharmaceutical industry has no incentive to invest in research into this area. ${ }^{178}$ One of the recommendations of this paper is therefore that research into the risks of repeat trial participation should be conducted.

(b) Issue two - inadequate disclosure of compounded risks

Although a volunteer can choose to accept the compounded risks of repeat trial participation, the author questions whether disclosure of these risks is likely to always occur in practice. Three arguments can be made to support this point:

1) There is limited information available on the compounded risks of repeat trial participation, and the New Zealand regulatory framework does not recognise these risks. By contrast, the risks of participating in a particular trial, in isolation from other trials, are heavily regulated. Researchers are required to conduct preclinical testing in order to estimate the toxicity of the trial drug in humans and the law requires this information to be submitted for assessment as part of the clinical trial approval process. Disclosure of the risks of trial participation is therefore likely to be based on the risks identified for the individual trial in question, and not on the largely unknown risks of repeat trial participation.

2) There is no centralised database of clinical trial participants so a researcher's knowledge of a volunteer's history of repeat trial participation rests solely on disclosure by that volunteer. However, given the lack of publicity regarding compounded risks, a volunteer may not consider it necessary to disclose their history of trial participation. This accords with the research done by Abadie, who found that volunteers' "perception[s] [of themselves] as 'contractors' being hired for individual trials made [them] consider the risks in the trial they were joining,

\footnotetext{
${ }^{177}$ Health Research Council of New Zealand Standing Committee on Therapeutic Trials: Terms of Reference (New Zealand Government); and see Part II(C).

178 Abadie, above n 4, at 8.
} 
but they did not consider the cumulative result of drug interactions resulting from years of trial participation". ${ }^{179}$

3) The Code of Rights requires informed consent to experimental procedures to be in writing. ${ }^{180}$ It is standard practice for volunteers to read and sign a participant information sheet and consent form. A participant information sheet and consent form provides a detailed description of a particular trial including the purpose of the study, the requirements of participating in the study, the possible risks and benefits of the study and the rights of research participants. ${ }^{181}$ It is mandatory for researchers to submit a participant information sheet and consent form specific to their trial to an ethics committee for ethical approval before the trial can be conducted in New Zealand. ${ }^{182}$ This requires the ethics committee to review the participant information sheet and consent form for compliance with the Ethical Guidelines. The Ethical Guidelines, however, have been drafted to address the issues arising from an individual trial only, and do not acknowledge that participants may participate in multiple trials. The guidance provided on informed consent therefore focuses on informed consent to particular clinical trial, in isolation from informed consent to the numerous other trials a professional volunteer has consented to. There is therefore no guidance requiring a participant information sheet and consent form to disclose the compounded risks of repeat trial participation. While it is clear that a signed participant information sheet and consent form alone is not enough to satisfy the requirement of informed consent, ${ }^{183}$ the researcher's disclosure of risks is likely to be based on the information in the participant information sheet and consent form and may therefore not include adequate disclosure of the compounded risks of repeat participation.

If a researcher does not disclose the compounded risks of repeat trial participation to a professional volunteer, that volunteer will be unable to give informed consent to participate in a trial. Informed consent is protected as a right in New Zealand by right seven of the Code of Rights, which provides that "services may be provided to a consumer only if that consumer

\footnotetext{
179 Abadie, above $\mathrm{n}$ 4, at 158 .

${ }^{180}$ Code of Health and Disability Services Consumers' Rights, cl 2, right 7(6)(a).

${ }^{181}$ Health and Disability Ethics Committees Participant Information Sheet and Consent Form Template.

182 Health and Disability Ethics Committees Standard Operating Procedures for Health and Disability Ethics Committees, Version 1 (Ministry of Health, ISBN: 978-0-478-39337-8 (online) HP 5507, May 2012) at 15.

183 Health and Disability Commissioner Anaesthetist (09HDC01691, 6 April 2011) at [85]; and Health and Disability Commissioner Ophthalmologist (97HDC4935, 22 April 1999).
} 
makes an informed choice and gives informed consent". ${ }^{184}$ Recent Health and Disability Commissioner decisions have interpreted the Code so that a breach of the right to be fully informed (right 6) results in a breach of the right to informed consent; the rationale being that if the health consumer does not receive sufficient information, he/she is not in a position to make an informed choice and give informed consent. ${ }^{185}$ Right 6 requires disclosure of the expected risks and side effects of trial participation. Thus, if participants in clinical trials are not adequately informed of the expected risks and side effects of their participation in the trial, there will be no informed consent. Right 6(2) provides the "the most obvious requirements" for what qualifies as adequate disclosure for the purposes of informed consent. ${ }^{186}$ It provides: ${ }^{187}$

Right 6 -Right to be Fully Informed

(2) Before making a choice or giving consent, every consumer has the right to the information that a reasonable consumer, in that consumer's circumstances, needs to make an informed choice or give informed consent.

The test is therefore based on the "reasonable consumer", but it also incorporates a subjective element: ${ }^{188}$

The test of what information should be supplied incorporates the objective element of the 'reasonable consumer' but considers this in light of the particular circumstances of the consumer whose rights are at issue, which is a subjective overlay.

The subjective element of the reasonable consumer test makes it clear that the assessment of risk must be "tailored" to the individual volunteer's circumstances. ${ }^{189}$ Adequate disclosure, in the case of a professional volunteer, would therefore require assessment of the risks of a particular trial, given the volunteer's individualised history of trial participation. This means that the compounded risks of repeat trial participation need to be disclosed to a professional volunteer before he/she can give legally effective informed consent under the Code of Rights. Given the analysis in Part III(C)(1), these risks also need to be disclosed in order for there to be consent for

\footnotetext{
${ }^{184}$ Code of Health and Disability Services Consumers' Rights, cl 2, right 7(1).

185 Health and Disability Commissioner Chiropractor (11HDC00231, 7 June 2013); Health and Disability Commissioner General Practitioner/Medical Centre (11HDC00871, 11 December 2012); Health and Disability Commissioner Dentist (10HDC00671, 26 June 2012); Health and Disability Commissioner Plastic Surgeon (10HDC00509, 27 February 2012); Health and Disability Commissioner Anaesthetist (09HDC01691, 6 April 2011); and Health and Disability Commissioner Urologist/Hospital (Private)/Nurse (08HDC20258, 11 November 2009).

${ }^{186}$ Skegg, above n 118, at 225.

${ }^{187}$ Code of Health and Disability Services Consumers' Rights, cl 2, right 6.

${ }^{188}$ Katharine Greig, above n 59.

${ }^{189}$ Health and Disability Commissioner Oral and Maxillofacial Surgeon (01HDC13700, 24 June 2003).
} 
the purposes of the right not to be subjected to medical experimentation without consent under the New Zealand Bill of Rights Act 1990. The point made in this section of the paper is that the lack of guidance on these increased risks makes it is likely that the compounded risks of repeat participation are not always adequately disclosed to professional volunteers.

\section{Proposals for reform}

This part of the paper will put forward and critique two proposals for addressing the two issues discussed above - exposure to unregulated compounded risks and inadequate disclosure of compounded risks. Paragraph (a) will evaluate the option of limiting the number of trials that volunteers can participate in and paragraph (b) will argue that participant information sheet and consent forms should be required to disclose the compounded risks of repeat trial participation.

(a) Limit the number of trials a volunteer can participate in

To cap the risk to which professional volunteers can expose themselves, a limit could be placed on the number of trials that a volunteer can participate in. This practice has been adopted in France. ${ }^{190}$ This also appears to be the solution favoured by Abadie. ${ }^{191}$ Such a limit would be inconsistent with the ethical principle of autonomy, because it would restrict the ability of professional volunteers to make their own decisions about the level of risk they are willing to accept. Although the right to informed consent is based in autonomy, informed consent is not the same thing as autonomy and it does not follow here that restricting autonomy breaches the right to informed consent. The right to informed consent does not mean that professional volunteers have a right to participate in limitless trials. The right is much narrower than this, providing that "services may be provided to a consumer only if that consumer makes an informed choice and gives informed consent". ${ }^{192}$ This proposed limit therefore does not breach the right to informed consent under the Code of Rights.

Although autonomy is a dominant principle of medical ethics which, as explained Part IV, does influence the development of regulation, autonomy is not absolute and it needs to be balanced against other interests. The wider regulatory framework in this case supports taking a paternalistic approach to the regulation of safety risks. Individual clinical trials are rigorously assessed for safety to participants as part of the scientific approval process discussed in Part

\footnotetext{
${ }^{190}$ CL Tishler and S Bartholomae "Repeat participation among normal healthy research volunteers: professional guinea pigs in clinical trials?” (2003) 46(4) Perspect Biol and Med 508 at 516.

${ }^{191}$ Abadie, above $\mathrm{n}$ 4, at 165.

${ }^{192}$ Code of Health and Disability Services Consumers' Rights, cl 2, right 7(1).
} 
II(C). Researchers are required to exclude particular participants from trials if they meet exclusion criteria, which are aimed at protecting volunteers who have a greater risk of experiencing adverse drug reactions or complications. If, after approval, the risks of a study are determined to be unacceptable the study will be terminated. In this context, it would be inconsistent to leave the compounded risks of repeat participation completely unregulated. Furthermore, limiting the risk that professional volunteers can expose themselves to advances the underlying ethical considerations of justice and non-maleficence, upon which the Ethical Guidelines are based. ${ }^{193}$ Ethical justice requires that "vulnerable members of a community should not bear disproportionate burdens of studies from which other members of the community are intended to benefit". ${ }^{194}$ The risks of trial participation are pooled in professional volunteers, yet the research is not intended to benefit them (at least directly) because they are healthy volunteers. Limiting the risks that volunteers can expose themselves to will reduce this pooling, and more evenly distribute the burden of research. ${ }^{195}$ It is also consistent with the obligation not to inflict harm on others, which is encompassed by the principle of non-maleficence.

Ultimately, any limit to the number of trials a volunteer can participate in should be determined on a case-by-case basis, taking into account the individual volunteer's risk profile, based on their specific history of trial participation. While there is limited information available on the risks of repeat trial participation, it is possible that there will be some cases in which the safety risks justify a limit. As explained above, a safety-based limit to autonomy is justifiable in light of the surrounding regulatory framework. The Ethical Guidelines should therefore be amended to acknowledge the risks of repeat participation, and to provide guidance to researchers to exclude participants from trials on the basis of unacceptable safety risks.

(b) Require participant information sheet and consent forms to disclose the compounded risks of repeat trial participation

In order to ensure that professional volunteers are always made aware of the risks of repeat trial participation, the Ethical Guidelines should be amended to require participant information sheet and consent forms to disclose these increased risks. Of course, any disclosure would have to be generalised, because participant information sheet and consent forms are standardised to a particular trial. However, such a disclosure would alert both volunteers and researchers to the compounded risks of trial participation, forming the basis for a more individualised discussion of risks.

\footnotetext{
193 See Part III(A).

${ }^{194}$ National Ethics Advisory Committee, above n 7, at 8.

195 Tishler and Bartholomae, above n 190, at 515.
} 
By ensuring that researchers comply with their obligations of information disclosure, this proposal is consistent with the right to informed consent under the Code of Rights, and, given the discussion in Part IIIC(1), it is also consistent with the right not to be subjected to medical experimentation without consent under the New Zealand Bill of Rights Act 1990.

\section{Dehumanisation and Commodification}

Dehumanisation and commodification of the human body are the two most difficult issues of professional trial participation and, as explained below, ${ }^{196}$ they are likely to form part of the reason why professional volunteers are not recognised by the existing regulatory framework. Both issues relate to a disembodiment of self, which Abadie describes as follows: ${ }^{197}$

One of the most important critiques of the pharmaceutical industry and the commodification of bodies in trials research is that the process not only exploits but dehumanises research subjects. The tendency of research subjects to identify themselves with guinea pigs conveys well this notion of disembodied self. It is also not rare for volunteers to resort to images of torture, sex work, or prostitution when describing their activities. And their emergent solidarity as professionals... and their everyday forms of resistance at work draw attention to their efforts to reassert their human condition.

Part 1 of this section will argue that the Ethical Guidelines, in failing to recognise the existence of professional volunteers, or even that volunteers may be motivated by financial reward, fail to address the dehumanisation (discussed in paragraph (a)) and commodification (discussed in paragraph (b)) experienced by professional volunteers.

Part 2 of this section will put forward and critique two proposals for addressing the issues of dehumanisation and commodification.

\section{Issues}

(a) A dehumanising profession

Professional trial participation can be viewed as dehumanising. The fact that professional volunteers commonly identify themselves as professional guinea pigs is evidence of this. ${ }^{198}$

\footnotetext{
196 See Part VI.

197 Abadie, above n 4, at 10-11.

198 At 47.
} 
Further, the accounts from self-identified professional guinea pigs in Abadie's book support this view. One interviewee referred to his profession in the "torture economy" as follows: 199

...you are not asked to produce or to do something anymore, you are being asked to endure something. So if you are a guinea pig you are enduring something, people are doing things to you and you are just enduring it, you are not actually producing something...It's a different type of activity, I still feel that there is some work in it but the nature of the work has changed. And I am letting people pay me in exchange for the control they have over me.

Another interviewee describes the profession as "dehumanising".200

...you are paid to take this risk and also for this kind of weird dehumanisation. It's funny, what gets me the most is getting EKGS [electrocardiograms], I guess. And it's funny because it's for my safety and it's not invasive, has no side effects, but I take my clothes off and these people start putting things over my naked chest and then is when I feel like a guinea pig more than a worker...It's something that most people wouldn't get through. The guinea pig part is also because they pay you just to demean you to animal status, you are just letting yourself be measured by the functions of your organs and stuff, something that most people wouldn't agree with.

The Ethical Guidelines do not address this issue because they do not acknowledge the existence of professional volunteers. The Code of Rights is also likely to be of limited use. While the rights to dignity and respect are relevant to dehumanising treatment, ${ }^{201}$ it is unlikely that professional volunteering breaches these rights. The rights in the Code of Rights place obligations on health care providers in respect of a particular health service. This means that as long as a researcher in a particular trial complies with the Code of Rights, there will be no breach. The issue of a dehumanising profession, however, cannot be isolated to a single trial. It is the cumulative result of participation in a number of trials. The currently regulatory framework therefore does not adequately address this issue.

(b) Commodification of the human body

Professional trial participation can also be viewed as a type of commodification of the human body. While not as extreme as the sale of organs, professional volunteers are paid to be

\footnotetext{
199 At 2-3.

${ }^{200}$ At 47.

${ }^{201}$ Code of Health and Disability Services Consumers’ Rights, cl 2, rights 1 and 3.
} 
experimented on and in this sense they do "sell their bodies to science". Abadie explains this well in his book: ${ }^{202}$

Paying healthy people to test drugs that they don't need is another step toward commodifying the body in biomedicine. But unlike those who sell a kidney or plasma, professional guinea pigs see their whole bodies become the commodity. Trial subjects are well aware of how valuable their bodies are, despite the protestations of the pharmaceutical industry that subjects are volunteers being compensated just for their time. They see themselves as workers, entering a professional and contractual relationship with the industry. Trials are their business, a way of making quick, easy money.

The Ethical Guidelines completely avoid this issue by not recognising that volunteers may be solely or primarily motivated to volunteer by financial compensation, let alone that they may participate in clinical trials as a profession. In relation to "benefits to participants", the Guidelines provide that: ${ }^{203}$

People have a range of motives for participating in intervention studies. These can include gaining benefit for themselves or for other individuals in the future, helping to contribute to knowledge, and contributing benefits to communities, including benefit sharing and reciprocity

This focus on altruism reflects the general characterisation of research participants as "volunteers" rather than workers motivated by financial incentives (although the Ethical Guidelines themselves, for the most part, refer to volunteers as participants, not volunteers). ${ }^{204}$ While this allows the Ethical Guidelines to avoid the difficult issue of commodification, it ignores the reality that professional volunteers do allow their bodies to be tested on in exchange for money, and that most of them are not altruistically motivated. The refusal of the Ethical Guidelines to recognise the commodification of professional volunteers does not stop their commodification, but it does stop researchers and ethics committees from being able to engage appropriately with this issue.

\section{Proposals for reform}

This part of the paper will put forward and critique two proposals for addressing the issues of commodification and dehumanisation. Paragraph (a) will evaluate the option of prohibiting

\footnotetext{
202 Abadie, above n 4, at 6.

${ }^{203}$ National Ethics Advisory Committee, above n 7, at 6.

${ }^{204}$ Abadie, above n 4, at 9.
} 
professional trial participation and paragraph (b) will argue that, in the absence of legislative intervention, the Ethical Guidelines should be amended to recognise professional volunteers as a class of research participants.

(a) Prohibit professional trial participation

Dehumanisation is an inherent and inescapable part of professional volunteering. Phase I trials are likely to require volunteers to be subjected to extensive testing, including periodic blood and urine tests, electrocardiograms and scans. Volunteers may be required to fast. The side effects from the drugs they test are likely to cause discomfort (or worse). Throughout the trial volunteers will be closely monitored. They may be required to stay at a clinical research facility for many days as an inpatient, and they may be woken throughout the night for testing. They may be required to refrain from unprotected sex for some time (maybe months) after participation. All of this contributes to the dehumanising nature of the profession, yet it is a necessary part of the clinical trial process. Therefore, the most effective means of addressing the dehumanisation of professional volunteers would be to prohibit professional trial participation. This would also be a potential solution to the commodification issue.

On the other hand, prohibiting professional trial participation would be inconsistent with the underlying ethical principle of autonomy, because it would prevent professional volunteers from choosing this profession. If regulation were to be solely based on the principle of autonomy, it would allow professional volunteers to consent to their dehumanisation and commodification. However, although autonomy is a dominant principle of medical ethics which, as explained in Part IV, does influence the development of regulation, autonomy is not absolute and it needs to be balanced against other interests.

In analogous areas, such as paid surrogacy and property in human body parts, legislation has been enacted to override autonomy and prohibit commodification of the human body. The Human Assisted Reproductive Technology Act 2004 prohibits and criminalises the commercial supply of human embryos or gametes and commercial surrogacy arrangements. ${ }^{205}$ The Human Tissue Act 2008 generally prohibits and criminalises trading in human tissue, ${ }^{206}$ which is consistent with the common law's general position that there can be no property in the human body. Thus, comparable regulation could provide justification for a prohibition on the commercialisation of human bodies for the purpose of clinical trials.

\footnotetext{
${ }^{205}$ Human Assisted Reproductive Technology Act, s 13-14.

${ }^{206}$ Human Tissue Act, s 56.
} 
Commercial surrogacy is particularly analogous to paid clinical trial participation, in the sense that in both practices a person's entire body becomes a commodity. Before the Human Assisted Reproductive Technology Act 2004, there was no legal ban on commercial surrogacy in New Zealand. $^{207}$ However, at that time, it was the practice of the National Ethics Committee on Assisted Human Reproduction (which was responsible for giving ethical approval to fertility clinics $)^{208}$ to only authorise altruistic surrogacy. ${ }^{209}$ The National Ethics Committee on Assisted Human Reproduction had, in 1997, agreed "to give ethical approval in principle for noncommercial altruistic surrogacy" and it subsequently developed "draft guidelines for noncommercial altruistic surrogacy using IVF as treatment". ${ }^{210}$ The focus of regulation has therefore always been on altruistic surrogacy. In enacting the Human Assisted Reproductive Technology Act 2004, Parliament appears to have largely defaulted to this position, ${ }^{211}$ and it is not clear from the legislative history exactly what Parliament's rationale for prohibiting commercial surrogacy was. $^{212}$ Commercial surrogacy can be objected to on the basis that it commodifies the surrogate mother's body. ${ }^{213}$ Of itself, this may be seen as a sufficient reason to warrant a prohibition of commercial surrogacy if commodification is characterised as "fail[ing] to respect or value human bodies in the appropriate way". ${ }^{214}$ However, other objections to commercial surrogacy are likely to have influenced Parliament's decision to prohibit it. Commercial surrogacy can be objected to on the basis that it is exploitative. ${ }^{215}$ It can also be viewed as violating the rights of the child. ${ }^{216}$ The commodification of the resulting child in surrogacy, or "baby selling" (as distinct from the commodification of the surrogate mother's body), is a particularly common objection. ${ }^{217}$ Returning to our underlying ethical principle, autonomy, the commodification of babies in surrogacy can be viewed as more ethically problematic than the commodification of the surrogate mother, because the surrogate mother can consent to the commodification, but the baby cannot. In the case of professional trial participants the analogy is drawn to the commodification of the surrogate mother, not the child, because professional trial participants also consent to their

\footnotetext{
${ }^{207}$ Human Assisted Reproductive Technology Bill (195-2) (select committee report) at 12.

${ }^{208}$ Ken Daniels "The Policy and Practice of Surrogacy in New Zealand" in Rachel Cook, Shelley Day Sclater and Felicity Kaganas Surrogate Motherhood: International Perspectives (Hart Publishing, Oxford, 2003) at 61.

${ }^{209}$ Human Assisted Reproductive Technology Bill (195-2) (select committee report) at 12.

${ }^{210}$ National Ethics Committee on Assisted Human Reproduction Annual Report to the Minister of Health for the year ending 31 December 2001 (Ministry of Health, ISBN 0-478-27071-2, June 2002) at 3.

${ }^{211}$ Human Assisted Reproductive Technology Bill (195-2) (select committee report) at 12.

${ }^{212}$ Human Assisted Reproductive Technology Bill (195-2) (select committee report) at 12; (6 October 2004) 620 NZPD 15899; (20 October 2004) 621 NZPD 16344; and (10 November 2004) 621 NZPD 16831.

${ }^{213}$ Anderson ES “Is Women's labor a commodity?” (1990) 19(1) Philosophy \& Public Affairs 71.

${ }^{214}$ Dickert and Grady, above n 2, at 391.

${ }^{215}$ Stephen Wilkinson "The exploitation argument against commercial surrogacy" (April 2003) 17(2) Bioethics 169.

${ }^{216}$ Hanna JK "Revisiting child-based objections to commercial surrogacy" (September 2010) 24(7) Bioethics 341.

${ }^{217}$ Law Commission New Issues in Legal Parenthood (NZLC R88, 2005) at 80.
} 
commodification. Given that the rationale for prohibiting commercial surrogacy may therefore have been based in a number of objections, Parliament may not consider it necessary to prohibit professional volunteering on the sole ground that it commodifies research participants.

For the reasons outlined below, the author supports the proposal set out in (b) - to amend the Ethical Guidelines to recognise professional volunteers as a class of research participants. However, given that legislation has been necessary in analogous areas, this paper recommends that the commercialisation of clinical trial participation warrants legislative attention. As discussed, this does not necessarily mean that professional trial participation will be prohibited, because commercial trial participation may be distinguishable. Further, in practice, clinical trial participation is already commercialised and this is something which is silently accepted as a necessary part of the clinical trial process. The author suspects that the uncomfortable, but unavoidable, reality is that our need for medical progress will outweigh any issues we may have with the dehumanisation and commodification that the commercialisation of trial participation presents. However, such a conclusion can only be reached by evidence-based policy decisions. Research into the necessity (or otherwise) of professional volunteers to the clinical trial industry will be required for this purpose.

If, ultimately, it is decided that a prohibition on professional trial participation is not justified, Parliament could adopt the approach taken to prostitution - an occupation which, as discussed above, professional volunteers identify with - to avoid the "moral issues" associated with commodification and dehumanisation. The Prostitution Reform Act 2004 recognises that prostitution presents issues warranting regulation, but neither endorses nor morally sanctions prostitution. ${ }^{218}$ This illustrates that regulation can be used to address harms without making a moral judgment. In any event, the social utility of clinical trial participation is likely to mean that society will accept it as less morally objectionable than prostitution, and therefore any issues of morality are likely to be more easily circumvented.

(b) Recognise professional volunteers as a class of research participants

The Human Assisted Reproductive Technology and Human Tissue Acts are evidence that regulation needs to address, rather than ignore, the comparable issues which arise in the case of professional volunteers. At the very least, the Ethical Guidelines should be amended to recognise the existence of professional volunteers as a class of research participants. The Ethical Guidelines already recognise a number of specific categories of vulnerable research participants, including older people, students, prison inmates and employees, and provide specific guidance

${ }^{218}$ Prostitution Reform Act 2004, s 3. 
on the various issues that arise from research on such participants. ${ }^{219}$ By recognising the existence of professional volunteers, the Ethical Guidelines would pave the way for an open discussion of the issues that this unique class of research participants presents.

This proposal would not prevent the dehumanisation and commodification of professional volunteers, which is an inescapable part of the profession. However, the fact that professional volunteers are currently ignored in New Zealand, and generally at an international level, is likely to contribute to the negative perception of their profession. Recognition and discussion of the issues facing professional volunteers should reduce the alienation of this profession, thereby making it less dehumanising. This is consistent with Abadie's findings, who describes the resistance movements and assertions of identify from professional guinea pigs in the United States as "efforts to reassert their human condition". 220

\section{Recommendations}

Professional volunteers are currently unrecognised and unregulated as a class of research participants. As explained above, this is despite the Ethical Guidelines specifically recognising and providing guidance on other classes of research participants. Professional trial participants are likely to be a relatively small population in New Zealand, ${ }^{221}$ and the issues which they face are not widely publicised. This might be one of the reasons why they are ignored by the Ethical Guidelines. In addition, regulation in this area tends to be prompted by an event which highlights the inadequacies of the law. For example, the TGN1412 tragedy in the United Kingdom prompted reform of the regulation of Phase I trials. ${ }^{222}$ In the United States, the Tuskegee syphilis experiments prompted the Belmont Report which reformed research ethics. ${ }^{223}$ Here in New Zealand, it was not until after the "Unfortunate Experiment at National Women's" and the release of the Cartwright Inquiry that the law of health consumer rights was radically reformed. ${ }^{224}$ However, the lack of regulation is also likely to be a result of regulators' reluctance to address the difficult issues of dehumanisation and commodification which arise in the case of professional volunteers. Indeed, New Zealand regulation does seem to deliberately avoid these

\footnotetext{
${ }^{219}$ National Ethics Advisory Committee, above n 7, at 46-61.

${ }^{220}$ Abadie, above $\mathrm{n} 4$, at 10-11.

${ }^{221}$ See Part II(B).

${ }^{222}$ Expert Group on Phase One Clinical Trials (Chairman: Professor Gordon W Duff) Expert Group on Phase I Clinical Trials: Final Report (The Stationary Office, ISBN-10 011703722 2/ ISBN-13 978011703722 9, 30 November 2006); and see Part V(B)(1).

${ }^{223}$ Tom L Beauchamp "The Belmont Report" in Ezekiel J Emanuel and others The Oxford Textbook of Clinical Research Ethics (Oxford University Press, New York, 2008) at 149.

${ }^{224}$ See Part IV(C).
} 
issues. As this paper has demonstrated, the Ethical Guidelines stress unrealistically that trial volunteers will have altruistic motivations. Further, industry practice seems to follow an unspoken rule that volunteers must be said to be compensated for "inconvenience", rather than paid for work. In relation to compensation given to trial participants, a 2012 Stuff article on "human guinea pigs" said, without authority: "they're not allowed to call it payment". 225 As Abadie explains, this contradiction is encapsulated by the oxymoron "paid volunteer": 226

As with organ transplantation, pharmaceutical corporations that conduct trials avoid referring to the commodification of the body in an attempt to maintain public trust. ... The industry refers to trial subjects with the oxymoron "paid volunteer," the pretence being that they are compensated not for their labour but for their "time and travel expenses".

Yet, professional volunteers exist despite the regulatory framework failing to acknowledge them. And as this paper has demonstrated, there are issues which arise in respect of this profession (in part because the regulatory framework ignores them) that need to be addressed. This paper therefore makes recommendations for further research and regulatory reform. The recommendations for further research can be summarised as follows:

1 Conduct empirical research into professional volunteers in New Zealand.

2 Conduct research into the risks associated with repeat trial participation.

3 Conduct research to determine whether professional volunteers are necessary for the viability of the clinical trial industry in New Zealand.

With regards to the recommendations for reform, the discussion in Part $V(C)(2)(a)$ led to the conclusion that professional trial participation warrants parliamentary attention. This is particularly so given the reluctance of the current regulators (the National Ethics Advisory Committee) to address the issues of commodification and dehumanisation. The status quo, however, cannot be maintained. In the event that Parliament does not intervene, this paper recommends that the Ethical Guidelines should be amended to recognise professional volunteers as a specific class of research participants, and to provide specific guidance on the issues that arise for these volunteers. In particular, the Ethical Guidelines should be amended to:

1 Acknowledge the risks of repeat participation, and provide guidance to researchers to limit participation in appropriate cases.

\footnotetext{
${ }^{225}$ Nikki Macdonald, above $\mathrm{n} 22$.

${ }^{226}$ Abadie, above n 4, at 9.
} 
2 Require participant information sheet and consent forms to disclose the compounded risks of repeat trial participation.

3 Expressly acknowledge that volunteers may be motivated to volunteer by financial reasons and to provide that financial compensation must be fair.

\section{VIIConclusion}

Clinical trials are already subject to comprehensive regulation. The Medicines Act 1981, Ethical Guidelines, Code of Rights and New Zealand Bill of Rights Act 1990 provide extensive protection to research participants, ensuring that, in general, research is ethical and scientifically sound. Calls for amendments or additional regulation in this highly regulated area of law need to be considered with caution. Regulation consumes resources and can restrict autonomy. Further, over-regulation could lead to pharmaceutical companies taking their clinical trials elsewhere. ${ }^{227}$ Therefore, any recommendations to increase regulation in this area should only be acted upon if they are necessary and justifiable in light of these considerations.

This paper has argued that professional volunteers fall through the gaps of current regulation, presenting unique issues which need to be recognised. This problem is not unique to New Zealand. At an international level professional volunteers are "a virtually unnoticed subpopulation of [healthy] volunteers". ${ }^{228}$ While the issues presented by professional volunteers appear to be largely untouched in New Zealand, there is considerable commentary on professional volunteers and calls for their regulation in other parts of the world. Abadie's book, which has formed the basis for discussion in this paper, provides a convincing argument for regulation in the United States. The recommendations proposed for New Zealand in this paper are largely directed at amending the Ethical Guidelines. They only require minor amendments to the existing regulatory framework which can be implemented with little cost. A comprehensive review of the Ethical Guidelines is planned for 2015, so the recommendations could be considered as part of this review process, which would also limit cost. ${ }^{229}$

The issues discussed in this paper are by no means the only issues presented by professional volunteers. Further, the recommendations advanced will not provide all the answers, and are only intended to be a starting point for discussion. This is a highly specialised and technical area of law which requires input and discussion from a wide range of groups, including lawyers,

\footnotetext{
${ }^{227}$ See Health Committee, above n 25.

228 Tishler and Bartholomae, above n 190, at 509.

${ }^{229}$ National Ethics Advisory Committee, above n 7, at v.
} 
clinicians, researchers and trial participants. What this paper hopes to achieve is to show that New Zealand needs to have this discussion. 


\section{BIBLIOGRAPHY}

PRIMARY SOURCES

A Cases

$1 \quad$ New Zealand

Brooker v Police [2007] NZSC 30; [2007] 3 NZLR 91

Down v Van de Wetering [1999] 2 NZLR 631

Federated Farmers of New Zealand Inc v New Zealand Post Ltd (1992) [1990-92] 3 NZBORR 339

McGrath v Police HC Auckland CRI-2011-404-110, 20 December 2011

PF v Capital and Coast District Health Board [2013] NZHC 1792

Pio v Police HC Rotorua AP43/94, 13 February 1995

Pio v Police HC Rotorua AP43/94, 4 July 1995

$R v$ Salmond [1992] 3 NZLR 8

Ransfield $v$ The Radio Network Ltd [2005] 1 NZLR 233

$S v W$ HC Auckland CIV-2011-404-3775, 7 December 2011

Television New Zealand Ltd v Solicitor-General [2008] NZCA 519 [2008] NZFLR 390

Taunoa v Attorney-General (2004) 7 HRNZ 379

WATCH (Waikato Against Toxic and Chemical Hazards) Inc v Attorney-General HC Hamilton CIV-2003-419-1265, 29 October 2003

$2 \quad$ United States

Trials of War Criminals Before the Nuremberg Military Tribunal Under Control Council Law 10 (1949) 2 Washington DC, United States Government Printing Office at 181-182 [The Nuremberg Code] cited in United States Department of Health and Human Services "The Nuremberg Code" <www.hhs.govt $>$

\section{B Legislation \\ $1 \quad$ New Zealand}

Crimes Act 1961 
Health and Disability Commissioner Act 1994

Health Research Council Act 1990

Human Assisted Reproductive Technology Act 2004

Human Tissue Act 2008

Medicines Act 1981

New Zealand Bill of Rights Act 1990

New Zealand Public Health and Disability Act 2000

Prostitution Reform Act 2004

Code of Health and Disability Services Consumers’ Rights Regulation 1996

$2 \quad$ United States

Code of Federal Regulations, Part 46 (Protection of Human Subjects)

\section{Health and Disability Commissioner Decisions}

Health and Disability Commissioner Anaesthetist (09HDC01691, 6 April 2011)

Health and Disability Commissioner Anaesthetist/Hospital (Public) (05HDC07699, 31 August 2006)

Health and Disability Commissioner Chiropractor (11HDC00231, 7 June 2013)

Health and Disability Commissioner Dentist (10HDC00671, 26 June 2012)

Health and Disability Commissioner General Practitioner/Medical Centre (11HDC00871, 11 December 2012)

Health and Disability Commissioner General Surgeon/Hospital (Private) (03HDC19128, 14 September 2004)

Health and Disability Commissioner Gynaecologist/Health Centre (01HDC01835, 30 June 2003)

Health and Disability Commissioner Neurosurgeon (98HDC13693, 6 December 2000)

Health and Disability Commissioner Ophthalmologist (97HDC4935, 22 April 1999)

Health and Disability Commissioner Oral and Maxillofacial Surgeon (01HDC13700, 24 June 2003)

Health and Disability Commissioner Plastic Surgeon (10HDC00509, 27 February 2012)

Health and Disability Commissioner Surgeon (97HDC9370, 23 April 1999)

Health and Disability Commissioner Urologist/Hospital (Private)/Nurse (08HDC20258, 11 November 2009) 


\section{Parliamentary Materials}

Geoffrey Palmer “A Bill of Rights for New Zealand: A White Paper” [1984-1985] I AJHR A6

Human Assisted Reproductive Technology Bill (195-2) (select committee report)

(6 October 2004) 620 NZPD 15899

(20 October 2004) 621 NZPD 16344

(10 November 2004) 621 NZPD 16831

\section{Government Publications}

Health Committee Inquiry into improving New Zealand's environment to support innovation through clinical trials (June 2011)

Law Commission New Issues in Legal Parenthood (NZLC R88, 2005)

\section{E Requests under the Official Information Act 1982}

Email from Susan Issacs (Standing Committee on Therapeutic Trials administrator) to Malisa Mulholland regarding the average number of Phase I studies approved by the Standing Committee on Therapeutic Trials per year (23 June 2013) (Obtained under Official Information Act 1982 Request to the Standing Committee on Therapeutic Trials)

\section{F Papers and Reports}

Expert Group on Phase One Clinical Trials (Chairman: Professor Gordon W Duff) Expert Group on Phase I Clinical Trials: Final Report (The Stationary Office, ISBN-10 011703722 2/ ISBN13978011703722 9, 30 November 2006)

Government Response to Report of the Health Committee on its Inquiry into improving New Zealand 's environment to support innovation through clinical trials, presented to the House of Representatives in accordance with Standing Order 248 (J.1) (6 September 2011)

Government Response to Law Commission Report on New Issues in Legal Parenthood (Ministry of Justice, March 2006)

Health and Disability Ethics Committees Participant Information Sheet and Consent Form Template

Health and Disability Ethics Committees Standard Operating Procedures for Health and Disability Ethics Committees, Version 1 (Ministry of Health, ISBN: 978-0-478-39337-8 (online) HP 5507, May 2012)

Health and Disability Ethics Committees Terms of Reference: Central Health and Disability Ethics Committee 
Health and Disability Ethics Committees Terms of Reference: Northern A Health and Disability Ethics Committee

Health and Disability Ethics Committees Terms of Reference: Northern B Health and Disability Ethics Committee

Health and Disability Ethics Committees Terms of Reference: Southern Health and Disability Ethics Committee

Health Research Council of New Zealand Standing Committee on Therapeutic Trials: Terms of Reference (New Zealand Government)

Medicines and Healthcare Products Regulatory Agency (UK) Investigations into Adverse Incidents during Clinical Trials of TGN1412 (May 2006)

National Ethics Advisory Committee Ethical Guidelines for Intervention Studies: Revised edition (Ministry of Health, July 2012)

National Ethics Advisory Committee Terms of Reference for the National Ethics Advisory Committee (February 2012)

New Zealand Medicines and Medical Devices Safety Authority Guideline on the Regulation of Therapeutic Products in New Zealand: Part 11: Clinical trials - regulatory approval and good clinical practice requirements, Edition 1.3 (Ministry of Health, November 2012)

Silvia Cartwright The Report of the Committee of Inquiry into allegations concerning the treatment of Cervical Cancer at National Women's Hospital and into other related matters 1988 (Government Printing Office, ISBN 0-473-00664-2, July 1988)

The National Commission for the Protection of Human Subjects of Biomedical and Behavioural Research Ethical Principles and Guidelines for the Protection of Human Subjects of Research (United States Department of Health and Human Services, 1978)

\section{SECONDARY SOURCES}

\section{G Books and Chapters in Books}

Alan Wetheimer "Exploitation in Clinical Research" in Ezekiel J Emanuel and others The Oxford Textbook of Clinical Research Ethics (Oxford University Press, New York, 2008)

Alastair Campbell, Grant Gillett and Gareth Jones Medical Ethics (3ed, Oxford University Press, Melbourne, 2001)

Andrew Butler and Petra Butler The New Zealand Bill of Rights Act: A Commentary (LexisNexis, Wellington, 2005)

Ezekiel J Emanuel, David Wendler and Christine Grady “An Ethical Framework for Biomedical Research" in Ezekiel J Emanuel and others The Oxford Textbook of Clinical Research Ethics (Oxford University Press, New York, 2008)

George J Annas and Michael A Grodin The Nazi Doctors and the Nuremburg Code: Human Rights in Human Experimentation (Oxford University Press, New York, 1992) 
Gerhard Nahler Dictionary of Pharmaceutical Medicine (2nd ed, Springer, Vienna, 2009)

Ilias Bantekas and Lutz Oette International Human Rights: Law and Practice (Cambridge University Press, New York, 2013)

Jim Hogshire Sell Yourself to Science: A Complete Guide to Selling Your Body Organs, Body Fluids, Bodily Functions and Being a Human Guinea Pig (Loompanics Unlimited, Port Townsend, 1992)

JK Mason and GT Laurie Mason \& McCall Smith's Law \& Medical Ethics (9ed, Oxford University Press, 2012)

Ken Daniels "The Policy and Practice of Surrogacy in New Zealand" in Rachel Cook, Shelley Day Sclater and Felicity Kaganas Surrogate Motherhood: International Perspectives (Hart Publishing, Oxford, 2003)

Kerry J Breen and others Good Medical Practice: Professionalism, Ethics and Law (Cambridge University Press, New York, 2010)

Leslie A Meltzer and James F Childress "What is Fair Participant Selection" in Ezekiel J Emanuel and others The Oxford Textbook of Clinical Research Ethics (Oxford University Press, New York, 2008)

Natalie Abrams and Michael D Buckner Medical Ethics: A Clinical Textbook, and Reference for the Health Care Professions (The MIT Press, United States of America, 1984)

Neal Dickert and Christine Grady "Incentives for Research Participants" in Ezekiel J Emanuel and others The Oxford Textbook of Clinical Research Ethics (Oxford University Press, New York, 2008)

Nicola Peart, Fiona McCrimmon and John Dawson "Clinical Trials" in John Dawson and Nicola Peart The Law of Research: a guide (University of Otago Press, Dunedin, 2003)

Paul Rishworth and others The New Zealand Bill of Rights (Oxford University Press, Melbourne, 2003)

PDG Skegg "Consent and Information Disclosure" in John Dawson and Nicola Peart The Law of Research: a guide (University of Otago Press, Dunedin, 2003)

PDG Skegg and Ron Paterson Medical Law in New Zealand (Brookers Ltd, Wellington, 2006)

Roberto Abadie The Professional Guinea Pig: Big Pharma and the Risky World of Human Subjects (Duke University Press, Durham, 2010)

Tom L Beauchamp "The Belmont Report” in Ezekiel J Emanuel and others The Oxford Textbook of Clinical Research Ethics (Oxford University Press, New York, 2008)

\section{H Journal Articles}

Anderson ES “Is Women's labor a commodity?” (1990) 19(1) Philosophy \& Public Affairs 71

CL Tishler and S Bartholomae "The recruitment of normal healthy volunteers: A review of the literature on the use of financial incentives" (2002) 42 J Clin Pharmacol 365 cited in CL Tishler and S Bartholomae "Repeat participation among normal healthy research volunteers: professional guinea pigs in clinical trials?” (2003) 46(4) Perspect Biol Med 508 
CL Tishler and S Bartholomae "Repeat participation among normal healthy research volunteers: professional guinea pigs in clinical trials?” (2003) 46(4) Perspect Biol and Med 508

Elliott Carl and Roberto Abadie "Exploiting a Research Underclass in Phase I Clinical Trials" (2008) 358(22) NEJM 2316

Giuseppe Pasqualetti and others "Healthy volunteers and early phases of clinical experimentation" (2010) 66 Eur J Clin Pharmacol 647

Hanna JK "Revisiting child-based objections to commercial surrogacy" (September 2010) 24(7) Bioethics 341

Jaillon P "Healthy volunteers' data bank: Where and how?" (1990) 4(2) Fundam Clin Pharmacol $177 \mathrm{~S}$ at $181 \mathrm{~S}$ cited in CL Tishler and S Bartholomae "Repeat participation among normal healthy research volunteers: professional guinea pigs in clinical trials?" (2003) 46(4) Perspect Biol and Med 508

Jerry Menikoff "Just Compensation: Paying Research Subjects Relative to the Risks They Bear" (2001) 1(2) AJOB 56

Laurie P Cohen "Stuck for money: To screen new drugs for safety, Lilly pays homeless alcoholics" (14 November 1996) WSJ (Eastern Edition) A1

Pamela R Ferguson “Clinical Trials and Healthy Volunteers” (2008) 16(1) Med Law Rev

Sheldon Zink "Maybe We Should Pay Them More” (2001) 1(2) Am J Bioethics 88

Stephen Wilkinson "The exploitation argument against commercial surrogacy" (April 2003) 17(2) Bioethics 169

Tolich M "What if Institutional Research Boards (IRBs) treated healthy volunteers in clinical trials as their clients?"(2010) 3(12) AMJ 767

\section{Laws of New Zealand}

Laws of New Zealand Human Rights (online ed)

\section{J Unpublished Papers}

Lyn Murphy and Dr William Maguire "Quantifying the Benefits and Costs of Conducting Sponsored Clinical Trials: Some Preliminary Results" (paper presented to the Auckland Region Accounting Conference, 2010)

Lucy M Trevelyan "Medical Experimentation on Humans: The Impact of Recent Legislation" (LLB(Hons) Dissertation, Victoria University of Wellington, 1992) 


\section{OTHER SOURCES}

\section{K Internet Materials}

Auckland Clinical Studies "About ACS" $<$ www.clinicalstudies.co.nz $>$

Auckland Clinical Studies "Completed \& Ongoing Studies" <www.clinicalstudies.co.nz $>$

Auckland Clinical Studies "Reimbursement" $<$ www.clinicalstudies.co.nz $>$

Christchurch Clinical Studies Trust "Reimbursement" $<$ www.ccst.co.nz $>$

Christchurch Clinical Studies Trust "Studies" $<$ www.ccst.co.nz $>$

Health and Disability Ethics Committees "About the Committees (26 October 2012)

$<$ ethics.health.govt.nz>

Health and Disability Commissioner "History" <www.hdc.org.nz $>$

Health and Disability Commissioner "The Code of Rights" <www.hdc.org.nz $>$

Health Research Council of New Zealand "Committees" <www.hrc.govt.nz $>$

Law Commission "Status of Parenthood" <www.lawcom.govt.nz $>$

Nikki Macdonald "The human guinea pigs" (12 August 2012) stuff.co.nz <www.stuff.co.nz $>$

Rebecca Gardiner "Backing clinical trials" (5 February 2013) Times Online <www.times.co.nz $>$

Robert Helms "Guinea Pig Zero: An Anthology of the Journal for Human Research Subjects" Guinea Pig Zero <www.guineapigzero.com $>$

U.S. National Institutes of Health "ClinicalTrials.gov" <www.clinicaltrials.gov>

\section{Magazine Articles}

Sandra Coney and Phillida Bunkle "An Unfortunate Experiment at National Women's" Metro (New Zealand, June 1987)

\section{Speeches}

Katharine Greig, Legal Manager "Informed consent in the Code of Health and Disability Services Consumer Rights" (presentation to the 8th Annual Medico-legal conference, 8 February 2000)

Ron Paterson Health and Disability Commissioner "Address to the $12^{\text {th }}$ Annual Release of the Cartwright Report” (presentation at Women's Health Action's function, 4 August 2000)

\section{N International Materials}


International Covenant on Civil and Political Rights 999 UNTS 171 (opened for signature 16 December 1966, entered into force 23 March 1976)

World Medical Association Declaration of Helsinki - Ethical Principles for Medical Research Involving Human Subjects (adopted by the 18th WMA General Assembly, Helsinki, Finland, June 1964) 